\title{
Review
}

\section{BH3 Mimetics in Hematologic Malignancies}

\author{
Pavel Klener ${ }^{1,2, *}$, Dana Sovilj ${ }^{3} \mathbb{C}$, Nicol Renesova ${ }^{2} \mathbb{D}$ and Ladislav Andera ${ }^{3,4}$ \\ 1 First Department of Internal Medicine-Hematology, General University Hospital in Prague, \\ 12108 Prague, Czech Republic \\ 2 First Faculty of Medicine, Institute of Pathological Physiology, Charles University, \\ 12108 Prague, Czech Republic; nicol.renesova@lf1.cuni.cz \\ 3 Institute of Biotechnology CAS/BIOCEV, 25250 Vestec, Czech Republic; dana.sovilj@ibt.cas.cz (D.S.); \\ Ladislav.Andera@ibt.cas.cz (L.A.) \\ 4 Institute of Molecular Genetics CAS, 14220 Prague, Czech Republic \\ * Correspondence: pavel.klener2@lf1.cuni.cz or pavel.klener2@vfn.cz
}

Citation: Klener, P.; Sovilj, D.; Renesova, N.; Andera, L. BH3 Mimetics in Hematologic Malignancies. Int. J. Mol. Sci. 2021, 22 10157. https://doi.org/10.3390/ ijms221810157

Academic Editor: Silvie Rimpelova

Received: 30 August 2021

Accepted: 17 September 2021

Published: 21 September 2021

Publisher's Note: MDPI stays neutral with regard to jurisdictional claims in published maps and institutional affiliations.

Copyright: (c) 2021 by the authors. Licensee MDPI, Basel, Switzerland. This article is an open access article distributed under the terms and conditions of the Creative Commons Attribution (CC BY) license (https:// creativecommons.org/licenses/by/ $4.0 /)$.
Abstract: Hematologic malignancies (HM) comprise diverse cancers of lymphoid and myeloid origin, including lymphomas (approx. 40\%), chronic lymphocytic leukemia (CLL, approx. 15\%), multiple myeloma (MM, approx. 15\%), acute myeloid leukemia (AML, approx. 10\%), and many other diseases. Despite considerable improvement in treatment options and survival parameters in the new millennium, many patients with HM still develop chemotherapy-refractory diseases and require re-treatment. Because frontline therapies for the majority of HM (except for CLL) are still largely based on classical cytostatics, the relapses are often associated with defects in DNA damage response (DDR) pathways and anti-apoptotic blocks exemplified, respectively, by mutations or deletion of the TP53 tumor suppressor, and overexpression of anti-apoptotic proteins of the B-cell lymphoma 2 (BCL2) family. BCL2 homology 3 (BH3) mimetics represent a novel class of pro-apoptotic anti-cancer agents with a unique mode of action-direct targeting of mitochondria independently of TP53 gene aberrations. Consequently, $\mathrm{BH} 3$ mimetics can effectively eliminate even non-dividing malignant cells with adverse molecular cytogenetic alterations. Venetoclax, the nanomolar inhibitor of BCL2 anti-apoptotic protein has been approved for the therapy of CLL and AML. Numerous venetoclaxbased combinatorial treatment regimens, next-generation BCL2 inhibitors, and myeloid cell leukemia 1 (MCL1) protein inhibitors, which are another class of $\mathrm{BH} 3$ mimetics with promising preclinical results, are currently being tested in several clinical trials in patients with diverse HM. These pivotal trials will soon answer critical questions and concerns about these innovative agents regarding not only their anti-tumor efficacy but also potential side effects, recommended dosages, and the optimal length of therapy as well as identification of reliable biomarkers of sensitivity or resistance. Effective harnessing of the full therapeutic potential of $\mathrm{BH} 3$ mimetics is a critical mission as it may directly translate into better management of the aggressive forms of HM and could lead to significantly improved survival parameters and quality of life in patients with urgent medical needs.

Keywords: apoptosis; $\mathrm{BH} 3$ mimetics; venetoclax; hematologic malignancies; targeted therapy; resistance; biomarkers

\section{Introduction}

Caspase-dependent apoptosis represents the most flexible and widely used regulated cell death (RCD) modality utilized in the animal kingdom by both invertebrates and vertebrates during embryonic development as well as in adult organisms with rapid and effective efferocytosis of dead cells [1]. Apoptotic signaling from a simplified mode (e.g., in C. elegans) evolved into a vast, though tightly regulated, signaling network in mammals. The intermediate as well as effector proteins in mammalian apoptotic signaling are specific proteases-caspases-which are both mediators of upstream apoptotic signaling (initiator caspases activated in specialized multiprotein complexes) and executioners of this signaling (effector caspases activated by active initiator caspases as well 
as by certain other proteases) [2,3]. Apoptotic signaling in mammalian cells can be triggered by exogenous/extrinsic stimuli such as death/dependence receptors or cytotoxic perforin/granzymes-containing granules and by a range of intrinsic stimuli. The intrinsic triggers of apoptotic signaling are associated with various cellular stresses such as damaged DNA, proteins, lipids (also ferroptotic signaling), organelles, increased levels of reactive oxygen species (ROS), energo-metabolic perturbations, and more. Importantly, cells with mitochondria primed by death signals have been shown to be addicted to antiapoptotic BCL2 molecules (primed for death), which can be exploited therapeutically [4] The majority of current anti-cancer drugs represent effective indirect activators of intrinsic mitochondria-dependent apoptotic signaling. The efficient triggering of either apoptotic signaling pathway relies on pronounced activation of the initiator caspases- 8 and /or -9 in respective multiprotein complexes-the death-inducing signaling complex (caspase-8) and apoptosome (caspase-9) [2]. Subsequent activation of a cohort of effector caspases (caspase$3,-6$, and -7 ) underlines the destructive phase of apoptotic signaling with hundreds of cleaved cellular proteins. Caspase-dependent apoptosis also represents the predominant non-inflammatory RCD mode triggered in the majority of hematologic and other malignancies [5]. Apoptotic blocks that prevent cancer cells from initiating programmed cell death in response to various pro-apoptotic stimuli represents one of the recognized hallmarks of cancer $[6,7]$.

\section{BCL2 Family of Apoptosis Regulators}

The BCL2 family of proteins contains 1-4 evolutionary-conserved BCL2 homology (BH) domains and can, in respect to cell survival, be formally divided into two groups$\mathrm{a} /$ inducing/enhancing or $\mathrm{b} /$ suppressing intrinsic/mitochondria-linked apoptosis. The former can be further subdivided into two groups-multidomain effectors of the intrinsic apoptosis BAX, BAK1, and BOK and BH3-only sentinels/activators/, which transduce a pro-apoptotic stress signal to the multidomain BCL2 family proteins (Figure 1) [8].

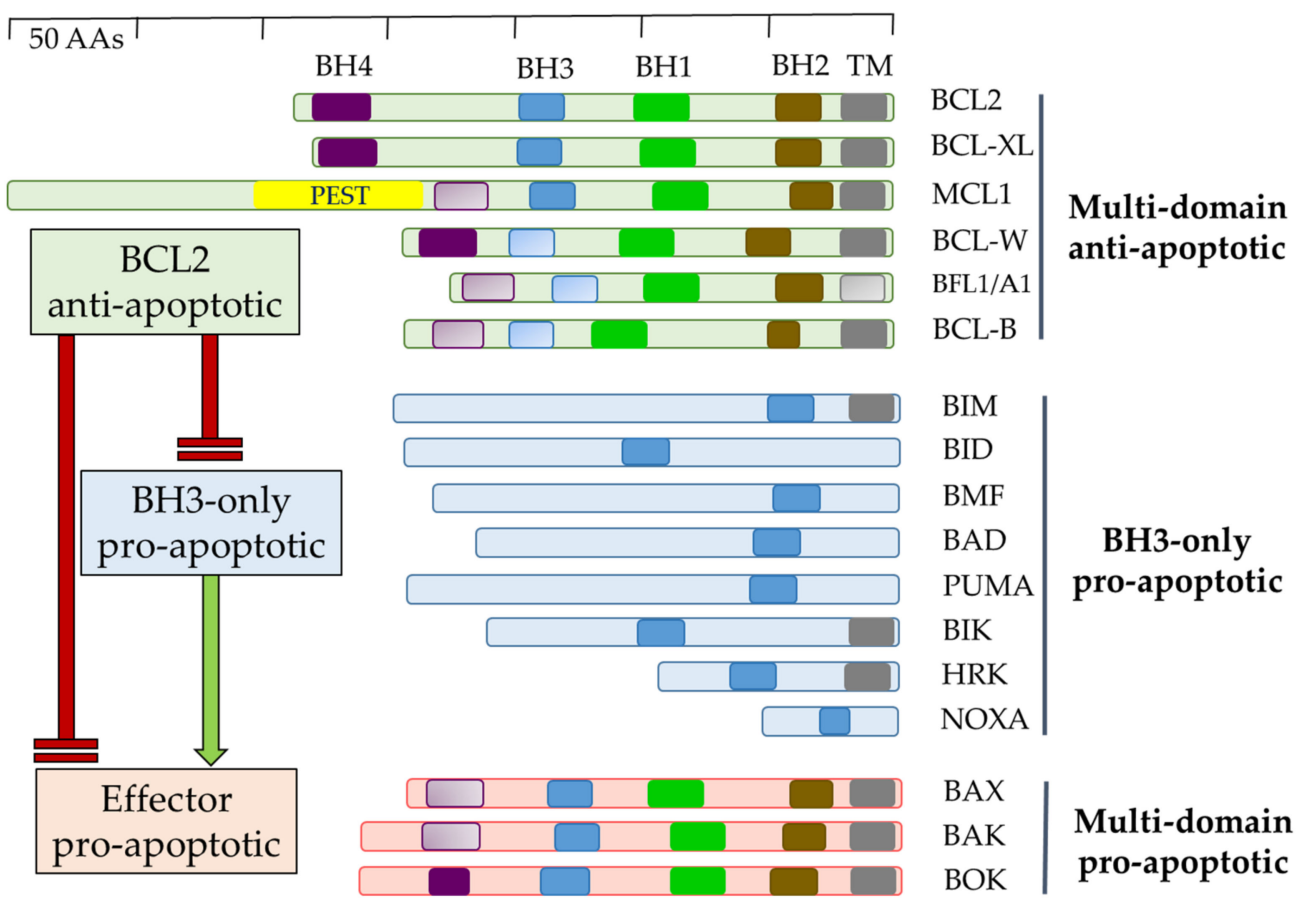

Figure 1. Overview of mammalian proteins of the BCL2 family. Multidomain anti-apoptotic and pro-apoptotic BCL2homology (BH) BH1-BH4 domains, and transmembrane (TM) domains are shown as opaque; presumed $\mathrm{BH}$ and TM domains are shown as transparent. PEST—signal peptide for protein degradation. 
The anti-apoptotic BCL2 family comprises six multi-BH domain (BH1-BH4) proteins, namely BCL2, BCL-XL, MCL1, BCL-W, BFL-1/A1, and BCL-B, which maintain balance by restricting multidomain pro-apoptotic proteins and sequestering $\mathrm{BH}$-only sentinels. $\mathrm{BCL}$ $\mathrm{XL}$ and MCL1 are essential for embryonic development as mice with eliminated expression of either one die during embryogenesis (day 13 or during preimplantation) (Table 1).

Table 1. Localization, non-apoptotic functions, and knockout phenotypes of anti-apoptotic BCL2 proteins.

\begin{tabular}{|c|c|c|c|c|}
\hline Protein & $\begin{array}{l}\text { Molecular Weight } \\
\text { (kD) }\end{array}$ & $\begin{array}{l}\text { Subcellular } \\
\text { Localization }\end{array}$ & $\begin{array}{l}\text { Non-Apoptotic } \\
\text { Functions }\end{array}$ & Knockout Mice \\
\hline BCL2 & 25 & $\begin{array}{l}\text { Mitochondria, ER, } \\
\text { nuclear envelope }\end{array}$ & $\begin{array}{l}\text { Autophagy, OxPhos, } \\
\text { regulation of } \mathrm{Ca}^{2+}\end{array}$ & $\begin{array}{l}\text { Viable ( } 50 \% \text { die after } 1-6 \text { weeks). } \\
\text { Rapid loss of immune cells, increased } \\
\text { sensitivity to apoptotic stimuli. }\end{array}$ \\
\hline BCL-XL & 30 & $\begin{array}{l}\text { Mitochondria, ER, } \\
\text { cytosol }\end{array}$ & $\begin{array}{c}\text { Shape of mitochonria, } \\
\text { autophagy, } \\
\text { DNA-damage response, } \\
\text { OxPhos, regulation } \\
\text { of } \mathrm{Ca}^{2+}\end{array}$ & $\begin{array}{l}\text { Lethal around embryonic day 13: } \\
\text { neuronal degradation, decreased } \\
\text { survival of lymphocytes and } \\
\text { erythrocytes, increased apoptosis of } \\
\text { hematopoietic precursors in liver. }\end{array}$ \\
\hline MCL1 & 40 & $\begin{array}{l}\text { Mitochondria, ER, } \\
\text { nuclear envelope, } \\
\text { cytosol }\end{array}$ & $\begin{array}{l}\text { Shape of mitochonria, } \\
\text { autophagy, OxPhos, } \\
\text { regulation of } \mathrm{Ca}^{2+}\end{array}$ & $\begin{array}{l}\text { Preimplantation lethality: reduction in } \\
\text { B and T lymphocytes, block of } \\
\text { lymphocyte differentiation. }\end{array}$ \\
\hline BCL-W & 19 & Mitochondria, cytosol & $\begin{array}{l}\text { Shape of mitochonria, } \\
\text { autophagy }\end{array}$ & $\begin{array}{l}\text { Viable. Male sterility and testicular } \\
\text { degeneration. }\end{array}$ \\
\hline A-1/BFL-1 & 20 & $\begin{array}{c}\text { Mitochondria, cytosol, } \\
\text { nucleus }\end{array}$ & Autophagy & $\begin{array}{l}\text { Viable. Increased neutrophile } \\
\text { apoptosis. }\end{array}$ \\
\hline
\end{tabular}

$\mathrm{ER}=$ endoplasmic reticulum, OxPhos = oxidative phosphorylation.

BH3-only pro-apoptotic BCL2 proteins form a diverse group of molecules that are induced/activated in response to various cellular stress signals. They can be released from cellular compartments (e.g., BCL2 interacting protein [BIM] or BCL2 modifying factor [BMF] from the cytoskeleton), transcriptionally upregulated (e.g., PUMA and NOXA in response to DNA damage via the TP53-dependent pathway), or activated (e.g., BH3 interacting domain death agonist [BID] cleaved by caspase-8 into truncated (t)BID) [9]. Stress stimuli that BH3-only proteins can recognize as apoptotic are heterogeneous in nature and include cytokine deprivation, anoikis, antigen receptor signaling, activation of oncogenes, DNA damage, chemotherapy drugs, or irradiation with UV light or $\gamma$ rays (Willis SN and Adams JM, 2005) [10]. Multidomain BCL2 family proteins contain, in addition to $\mathrm{BH}$ domains, a C-terminal transmembrane domain (TM) allowing them to associate with intracellular membranes such as the mitochondrial outer membrane (MOM), endoplasmic reticulum (ER), and nuclear membranes [11]. Their embedding into MOM is instrumental both for their anti-apoptotic and pro-apoptotic roles. During cellular homeostasis anti-apoptotic BCL2 proteins restrict BCL2 associated X (BAX) or BCL2 antagonist/ killer 1 (BAK1) from being multimerized by direct binding to them as well as buffering basal levels of BH3-only proteins. Upon pro-apoptotic cellular stress, induction/activation of various BH3-only BCL2 proteins leads to the release of BAX/BAK1 effector proteins from the anti-apoptotic BCL2 molecules. Released BAX/BAK1 then unfold in the MOM and, with the assistance of some BH3-only proteins (e.g., BID, BIM), or rather their C-terminal parts [12,13], they initially form homodimers gradually aggregating in the MOM and forming channels allowing the release of cytochrome $\mathrm{c}$ and other proteins from the mitochondrial intermembrane space in a process called mitochondrial outer membrane permeabilization (MOMP) [14,15]. Interestingly, MOMP does not always lead to irreversible apoptosis, but a small fraction of mitochondria with permeabilized MOM in the cell can be tolerated [16]. Consequently, MOMP no longer strictly defines the point of no return in the apoptotic process, but this "minority MOMP" can promote genome instability and contribute to the complex process of tumorigenesis. 


\section{BCL2}

\subsection{BCL2 and Its Role in the Regulation of Apoptosis and Other Cellular Processes}

BCL2, a $25 \mathrm{kD}$ protein coded on 18q21.3, was originally discovered as a translocation partner in patients with follicular lymphoma (FL) and other B-cell malignancies [17-19]. It was soon recognized that BCL2 was involved in the regulation of apoptosis and that it cooperated with the MYC oncogene in lymphoma pathogenesis [20-23]. BCL2 contains a conserved globular BCL2 core comprising eight $\alpha$-helices and a C-terminal transmembrane helix [24]. The C-terminus contains hydrophobic amino acids, which allow posttranslational localization of the BCL2 protein into intracellular membranes, predominantly the MOM, endoplasmic reticulum, and nuclear envelope [25]. Studies on BCL2 knockout mice revealed post-natal growth retardation, development of polycystic kidneys, and a massive loss of lymphocytes, probably due to involution of the spleen [26,27]. Interestingly, loss of even one allele of the pro-apoptotic BH3-only protein BIM rescued all of these abnormalities, pointing to an essential role of BCL2-BIM interactions [28]. In addition to $\mathrm{BIM}$, other BH3-only proteins, BAD, PUMA, and BID, interact with BCL2 upon diverse apoptotic stimuli and sequester it from the pro-apoptotic BAX or BAK1 [10]. Besides their undisputed role in apoptosis, BCL2 and other anti-apoptotic BCL2 family members participate in other cellular processes [29]. Moreover, BCL2 negatively regulates autophagy by direct binding to Beclin-1. BCL2 also participates in the regulation of cellular calcium levels [30] via its interaction with ligand-gated $\mathrm{Ca}^{2+}$ channels in the ER and might serve as a link between the ER and mitochondria [31,32]. Together with BCL-XL, BCL2 can impose cell cycle delay by prolonging the $\mathrm{G}_{0}$ phase through upregulation of the cell cycle inhibitor p27 [33,34]. In addition to its crucial apoptosis-modulating role, BCL2 enhances oxidative phosphorylation through binding to cytochrome c oxidase [35,36].

\subsection{BCL2 and Hematologic Malignancies}

In addition to follicular lymphoma (FL), overexpression of BCL2 through several distinct molecular mechanisms was found in most B-cell lymphoproliferative disorders and myeloid malignancies (Table 2) [37-52]. BCL2 gene aberrations and/or upregulated BCL2 protein repeatedly correlated with shorter PFS or OS [53-55].

Table 2. BCL2 expression and mechanisms of BCL2 deregulation in hematologic malignancies.

\begin{tabular}{|c|c|c|c|c|}
\hline Disease & $\begin{array}{c}\text { Dependence on } \\
\text { BCL2 and/or MCL1 }\end{array}$ & $\begin{array}{c}\text { Proportion of BCL2 } \\
\text { Positivity }\end{array}$ & $\begin{array}{l}\text { Molecular Mechanism(s) of } \\
\text { BCL2 Dysregulation }\end{array}$ & $\begin{array}{l}\text { Proportion of Patients } \\
\text { with the Aberration }\end{array}$ \\
\hline \multirow{2}{*}{ FL } & \multirow{2}{*}{ BCL2 } & \multirow{2}{*}{$>90 \%$} & $t(14 ; 18)(q 32 ; q 21)$ & $90 \%$ \\
\hline & & & $B C L 2$ mutations & \\
\hline \multirow{3}{*}{ DLBCL-GCB } & \multirow{3}{*}{ BCL2 and MCL1 } & \multirow{3}{*}{$70 \%$} & $t(14 ; 18)(q 32 ; q 21)$ & $30 \%$ \\
\hline & & & $B C L 2$ mutations & $10 \%$ \\
\hline & & & Hypermutation of $B C L 2$ promotor & \\
\hline \multirow{2}{*}{ DLBCL-ABC } & \multirow{2}{*}{ BCL2 and MCL1 } & \multirow{2}{*}{$90 \%$} & $18 q 21$ amplifications & $20 \%$ \\
\hline & & & $t(14 ; 18)(q 32 ; q 21)$ & $5 \%$ \\
\hline \multirow{2}{*}{ MCL } & \multirow{2}{*}{ BCL2 > MCL1 } & \multirow{2}{*}{$100 \%$} & $18 q 21$ gain & $20 \%$ \\
\hline & & & Cyclin D1 overexpression & $100 \%$ \\
\hline MZL & BCL2 & $80 \%$ & & \\
\hline CLL & BCL2 & $100 \%$ & $13 q 14$ loss (miR-15a, miR-16-1) & $50 \%$ \\
\hline $\mathrm{BL}$ & MCL1 & $0 \%$ & & \\
\hline MM & MCL1 > BCL2 & $60 \%$ & Cyclin D1 overexpression & $20 \%$ \\
\hline AML & BCL2 and MCL1 & $70-100 \%$ & & \\
\hline
\end{tabular}

$\mathrm{ABC}=$ activated B-cell; $\mathrm{AML}=$ acute myeloid leukemia; $\mathrm{BL}=$ Burkitt lymphoma; $\mathrm{CLL}=$ chronic lymphocytic leukemia; $\mathrm{DLBCL}=$ diffuse large B-cell lymphoma; $\mathrm{FL}$ = follicular lymphoma; $\mathrm{GCB}=$ Germinal center B-cell; $\mathrm{MM}$ = multiple myeloma; $\mathrm{MCL}=$ mantle cell lymphoma; MZL = marginal zone lymphoma. 


\subsection{BCL2 as a Therapeutic Target and a BH3 Mimetics Class of Agents}

Since the discovery of its role in malignant cell survival, BCL2 has appeared as a rational therapeutic target, but the early attempts to inhibit BCL2 were rather disappointing. An antisense oligonucleotide oblimersen (G3139) did not demonstrate survival benefit in patients with acute myeloid leukemia (AML) and multiple myeloma (MM) [56,57]. Similarly, obatoclax, the first $\mathrm{BH} 3$ mimetic tested in human subjects with relapsed/refractory (R/R) CLL had only limited clinical activity [58]. BH3 mimetics represent small molecule chemicals designed to bind and block the prosurvival groove of anti-apoptotic BCL2 family proteins thereby eliciting dose-dependent activation of BAX and BAK1 [59]. Another BH3 mimetic, a dual BCL2/BCL2L1 (BCL-XL) inhibitor navitoclax (ABT-737) demonstrated clinical activity in patients with $\mathrm{R} / \mathrm{R} \mathrm{CLL}$, but the overall response rate was rather low and administration of navitoclax was associated with severe "on-target" thrombocytopenia attributable to high-affinity inhibition of BCL-XL in megakaryocytes [60-62]. ABT-737, a predecessor of orally applicable ABT-263 was prepared by nuclear magnetic resonance (NMR)-assisted structure-based modulation of a compound selected from a chemical library that strongly interacted with the BH3-binding hydrophobic groove of BCL-XL/BCL2 and induced apoptosis of various human cancer cell lines at submicromolar concentration (Figure 2) [63]. A similar strategy was used for the design of the first nanomolar inhibitor of BCL2 ABT-199/venetoclax for the generation of the first selective inhibitor of MCL1 S63845, as well as for the derivation of highly-specific BCL-XL inhibitors A1155463 and WEHI-539 [64-68]. Thus, at least for BH3 mimetics, structure-based design and fine modulation of their selectivity and activity undoubtedly represent a perspective approach for enlarging the family of potent and safe anti-cancer drugs targeting anti-apoptotic BCL2 family proteins $[69,70]$.

A.

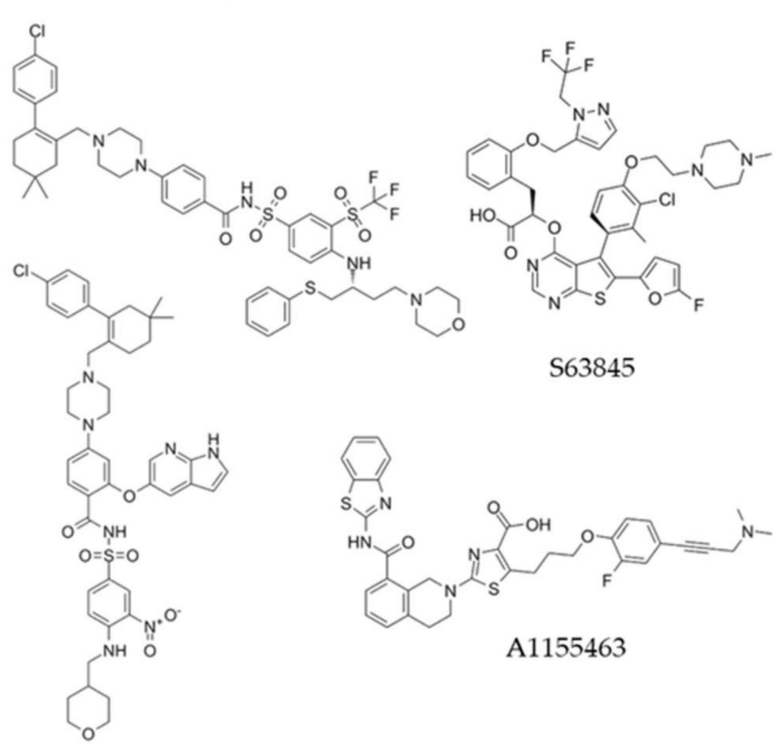

B.

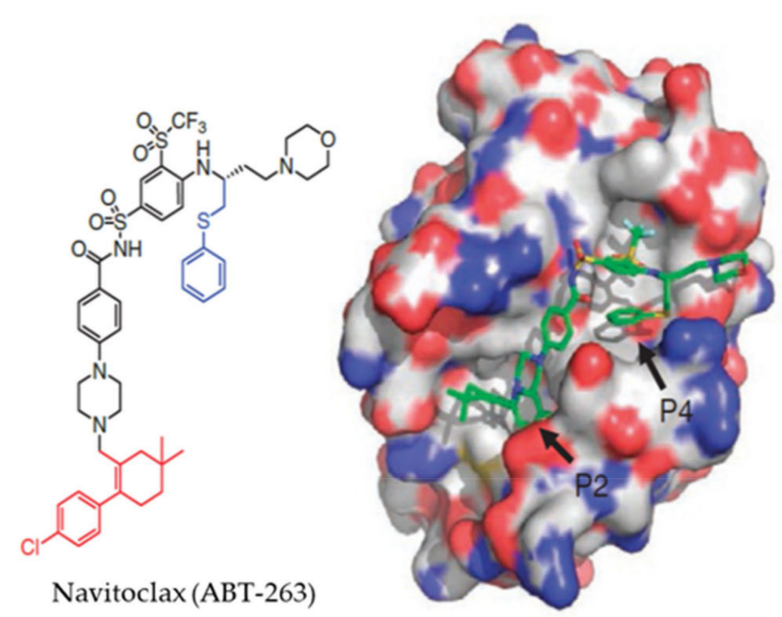

Venetoclax (ABT-199)

Figure 2. Selected BH3 mimetics targeting the anti-apoptotic BCL2 family proteins. (A) Molecular formulas of representative BH3 mimetics binding to/blocking BCL2/BCL-XL (navitoclax), BCL2 (venetoclax), MCL1 (S63845), or BCL-XL (A1155463); (B) Graphical representation of navitoclax and its binding to the hydrophobic groove of BCL2 protein (P2, P4-navitoclaxbinding BCL2 hydrophobic pockets). Reproduced from [65] with permission from Springer Nature publishing house.

\subsection{Venetoclax}

In sharp contrast, the nanomolar BCL2-specific inhibitor venetoclax (ABT-199, GDC0199) proved effective in most hematologic malignancies and was soon approved for 
the therapy of patients with CLL and AML (Table 3) [65,71-75]. Besides the currently approved indications, venetoclax demonstrated promising clinical activity in patients with mantle cell lymphoma (MCL), a lymphoma subtype molecularly characterized by the translocation $\mathrm{t}(11 ; 14)$ leading to overexpression of cyclin D1 [76]. Notably, the most robust in vitro and in vivo activity of venetoclax in MM was also observed in the cell lines and subcohort of patients harboring this translocation. Similarly, venetoclax can induce deep remissions in patients with $\mathrm{t}(11 ; 14)$-positive AL amyloidosis [77]. Despite the clear positive correlation between $t(11 ; 14)$ and sensitivity to venetoclax, the precise molecular rationale for the observed BCL2 dependence of the cases with $t(11 ; 14)$ remain largely elusive [78]. In treatment-naive diffuse large B-cell lymphoma (DLBCL) patients, venetoclax, in combination with standard immunochemotherapy (R-CHOP), improved PFS, especially in the BCL2-positive (i.e., detectable by immunohistochemistry (IHC)) subgroup $[79,80]$.

Table 3. Clinically approved indications of venetoclax.

\begin{tabular}{ccc}
\hline Disease & Regimen & Treatment Status \\
\hline CLL & Venetoclax monotherapy & $\begin{array}{c}\text { In the presence of TP53 aberration for patients, who have failed or } \\
\text { who are not suitable for Bruton tyrosine-kinase inhibitor } \\
\text { In the absence of TP53 aberration for patients, who have failed both } \\
\text { chemoimmunotherapy and Bruton tyrosine-kinase inhibitor }\end{array}$ \\
\hline CLL & Venetoclax + Rituximab & Patients, who relapsed after at least one line of therapy \\
\hline CLL & Venetoclax + Obinutuzumab & Untreated patients \\
\hline AML & Venetoclax + hypomethylating agent & Newly dg. patients ineligible for intensive therapy \\
\hline
\end{tabular}

$\mathrm{AML}=$ acute myeloid leukemia, $\mathrm{CLL}=$ chronic leukocytic leukemia.

\subsubsection{Venetoclax Mode of Action and Tumor Lysis Syndrome}

Unlike chemotherapy, venetoclax can trigger cell death not only in the actively dividing cells but also in the resting malignant cells, including cells with deregulated DNA damage response pathways, namely aberrations of tumor suppressor genes TP53, ATM, and complex karyotype changes $[81,82]$. Indeed, venetoclax can induce deep remissions, including molecular remissions, as measured by minimal residual disease (MRD) assessment in CLL and AML patients [83,84]. On the other side, the massive activation of apoptosis in cancer cells can lead to serious side effects including the life-threatening tumor lysis syndrome (TLS), especially in patients with a high tumor burden, heavily leukemized cases, or patients with renal impairment [85-87]. In some studies, venetoclax is being studied as a consolidation after chemotherapy-based debulking for targeted MRD eradication (with no risk of TLS) [82].

\subsubsection{TP53 Mutational Status and Venetoclax Efficacy}

Despite the efficacy of venetoclax toward TP53-deleted/mutated malignant cells has been repeatedly confirmed by many independent researchers, the most recent data brought evidence that the tumor suppressor function of $\mathrm{p} 53$ is nevertheless requisite for sustaining durable responses to venetoclax $[88,89]$. A subcohort of AML patients with mutated TP53 treated with the combination of venetoclax and decitabine had significantly lower response rates and shorter survival parameters compared to patients with wild-type TP53 [90].

\subsubsection{Non-Canonical Modes of Venetoclax Action}

Besides blocking prosurvival BCL2 signaling in various types of malignant cells, venetoclax shows some non-canonical anti-tumor activities. It has been shown to directly suppress oxidative phosphorylation (OxPhos) in leukemia stem cells leading to their targeted elimination [91]. This anti-metabolic activity of venetoclax was synthetically lethal with inhibitors of respiratory complex I [92]. Notably, venetoclax-induced metabolic reprogramming was found to be independent of BCL2 expression [93]. This off-target metabolic 
effect could be responsible for some of the observed venetoclax side effects and lead to unexpected drug-drug interactions. Additionally, venetoclax directly enhances T cell-mediated cytotoxicity by increasing reactive oxygen species generation through the inhibition of respiratory chain supercomplexes in non-malignant T cells [94]. Interestingly, metabolic reprogramming conferred acquired venetoclax resistance in lymphoid malignancies [95].

\subsubsection{Mechanisms of Resistance to Venetoclax}

Venetoclax-induced release of BIM sequestered by BCL2 represents the dominant mode of action of the BCL2 inhibitor (Figure 3A,B).

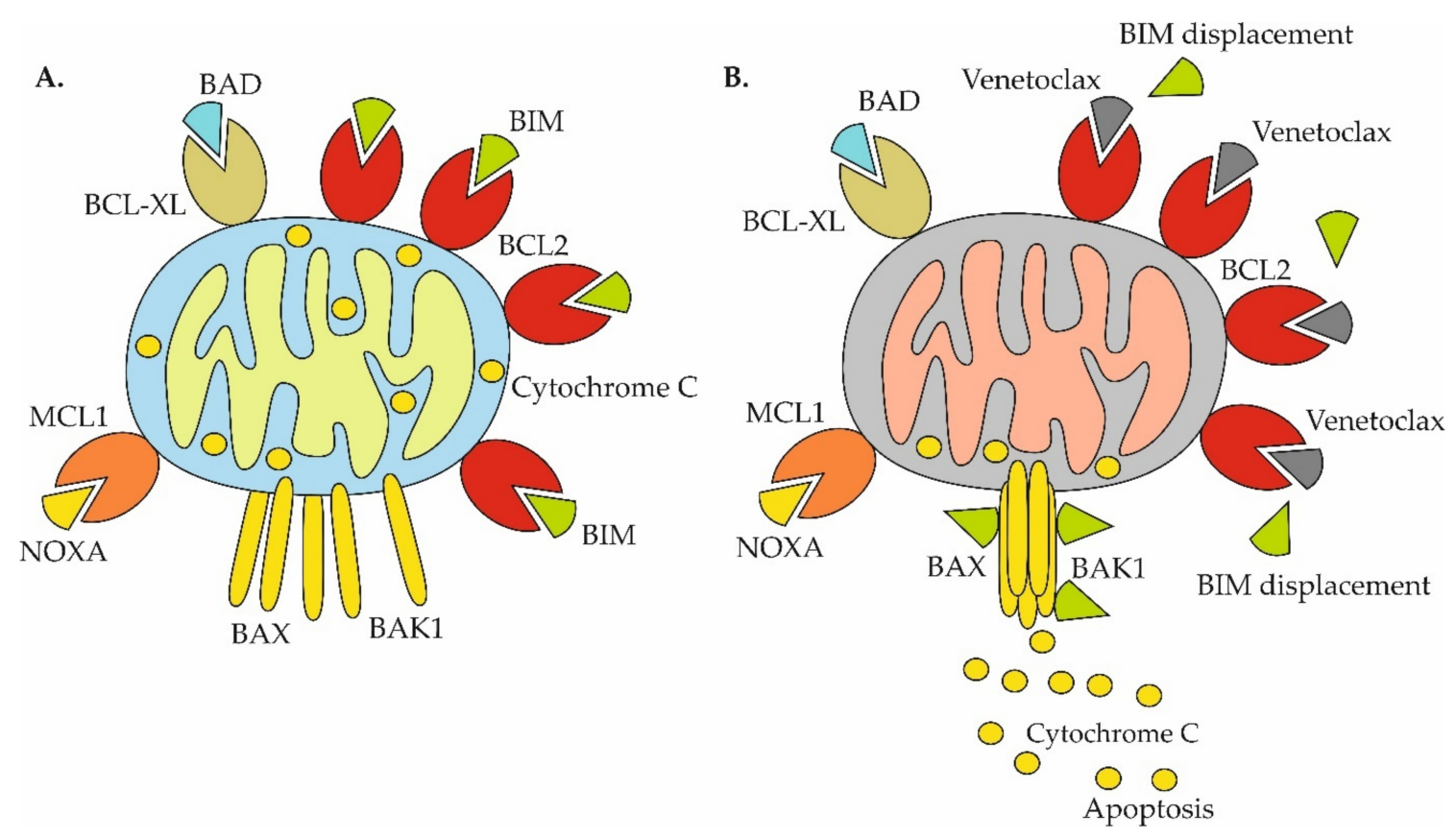

Figure 3. Mechanisms of venetoclax-triggered apoptosis in cells primed for death. (A) Cells primed for death: antiapoptotic BCL2 proteins (BCL2, BCL-XL, MCL1) are fully occupied by pro-apoptotic BH3-only proteins (BIM, BAD, NOXA); (B) Venetoclax causes displacement of BIM from BCL2 with subsequent assembly of BAX/BAK1 multiprotein complex, mitochondrial outer membrane permeabilization and release of cytochrome $\mathrm{c}$ and activation of apoptosis.

Similarly, upregulation of other key anti-apoptotic proteins, MCL1 and/or BCL-XL, was repeatedly associated with acquired resistance to venetoclax (Figure 4).

Reduced mitochondrial priming was confirmed in AML primary cells and patientderived xenograft (PDX) models [96]. Detailed molecular mechanisms that underlie the observed upregulation of MCL1 and BCL-XL remain only partially understood. First, NFKB-mediated upregulation of BCL-XL because of CD40-CD154 ligation was repeatedly associated with resistance to venetoclax in CLL cells in the lymph node microenvironment [97]. In addition to that, BCL-XL is directly transactivated by hypoxia-inducible factor 1-alpha (HIF1-alpha) [98,99]. It can be speculated that leukemia or lymphoma cells that reside in the hypoxic lymph node microenvironment might be selected for venetoclax resistance through multiple adaptive steps in a Darwinian fashion. Recently, Haselager et al. demonstrated that BCL-XL appears to play a more important role in mediating resistance to venetoclax than MCL1 [100]. 


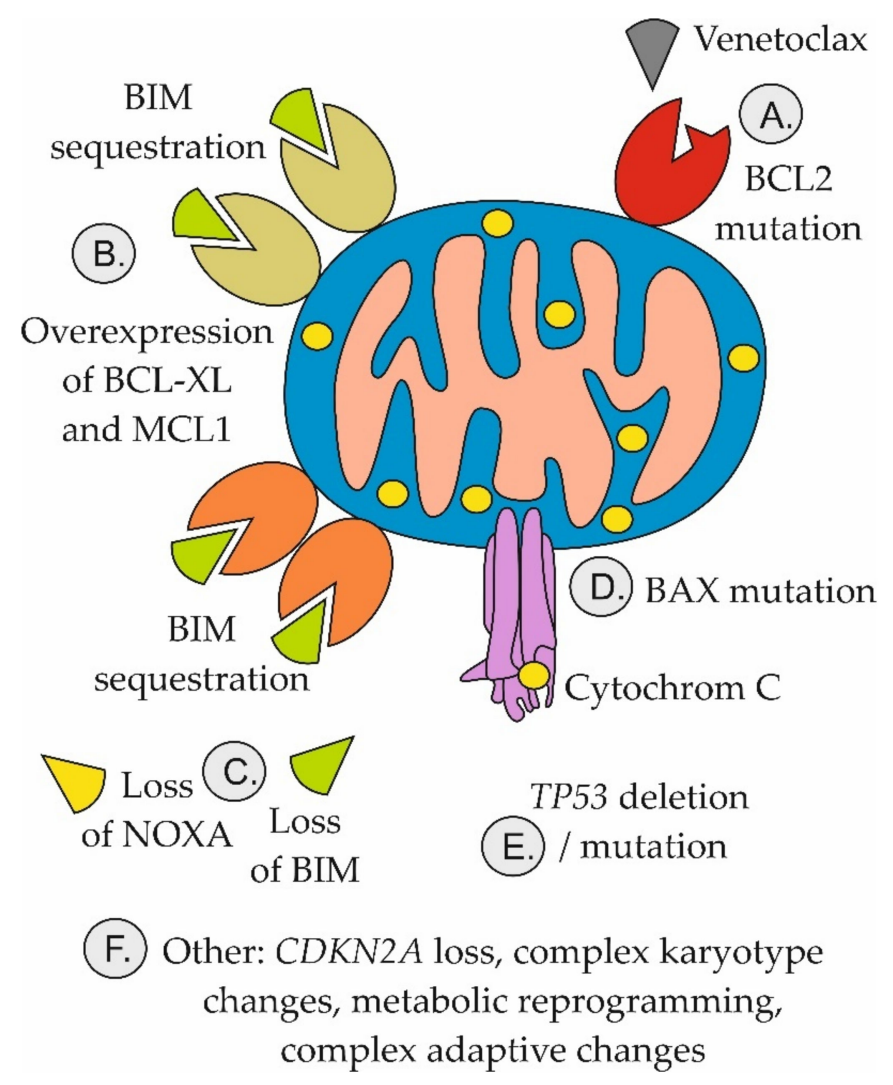

Figure 4. Mechanisms of resistance to venetoclax. (A) Mutation of BCL2 prevents binding of venetoclax to BCL2; (B) Adaptive overexpression of BCL-XL and/or MCL1 leads to sequestration of BIM released from BCL2; (C) Loss of NOXA or BIM attenuates the potential of venetoclax to trigger apoptosis; (D) BAX mutations prevent activation of mitochondrial apoptosis; (E) TP53 aberrations block mitochondrial apoptosis and facilitate selection of venetoclax resistance clones; (F) Other mechanisms include multiple genetic, epigenetic, and metabolic changes, the role of which in mediating venetoclax resistance are only partially understood.

$B C L 2$ mutations that reduce venetoclax binding sufficient to confer resistance, e.g., $B C L 2$ Gly101Val, have been reported in CLL patients [95,101-103]. Importantly, cells that did not harbor $B C L 2$ mutations had overexpressed BCL-XL. The data clearly demonstrate a polyclonal nature of the acquired venetoclax resistance. In contrast to CLL, BCL2 mutations are largely dispensable for acquired venetoclax resistance in AML [104]. Instead, somatic mutations of PTPN11 and KRAS, and upregulation of BCL2BFL-1/A1,CLC7A, and SF3B1 conferred resistance to venetoclax [105]. Likewise, the absence of BAX or NOXA (PMAIP1), overexpression of BCL-XL or MCL1, and mutation of TP53 all impart venetoclax resistance [106,107]. Other mechanisms of venetoclax resistance in AML include disrupted mitochondrial homeostasis with increased OxPhos as a result of upregulated amino acid and/or fatty acid oxidation $[108,109]$. In MCL, venetoclax resistance is also predominantly associated with non-BCL2 gene alterations including TP53, CDKN2A, KMT2C/D, SMARCA4, or NOTCH2 [110].

\subsubsection{Rational Venetoclax Combinations}

Venetoclax in combination with hypomethylating agents (HMA, azacytidine, and decitabine) or with anti-CD20 monoclonal antibodies (rituximab, obinutuzumab) belong to the only currently approved therapeutic combinations in human subjects (Table 4). Molecular mechanisms responsible for the observed synthetic lethality between venetoclax and HMA are summarized in Figure 5. 
Table 4. Selected clinical trials that incorporate venetoclax in experimental therapy of hematologic malignancies.

\begin{tabular}{|c|c|c|c|c|c|}
\hline Agent(s) & $\begin{array}{l}\text { Mode of Action of the Agents Used in } \\
\text { Combination with Venetoclax }\end{array}$ & Study Phase & Target Disease & $\begin{array}{l}\text { Estimated Study } \\
\text { Completion Date }\end{array}$ & $\begin{array}{l}\text { ClinicalTrials.gov Identifier } \\
\text { (Other Identifier) }\end{array}$ \\
\hline $\begin{array}{l}\text { Venetoclax }+ \text { Acalabrutinib } \\
+/- \text { Obinutuzumab }\end{array}$ & $\begin{array}{l}\text { Bruton tyrosine-kinase inhibitor }+ \\
\text { anti-CD20 antibody }\end{array}$ & 3 & CLL & March 2024 & NCT03836261 \\
\hline Venetoclax + Ibrutinib & Bruton tyrosine-kinase inhibitor & 3 & MCL & September 2022 & NCT03112174 (SYMPATICO) \\
\hline $\begin{array}{l}\text { Venetoclax }+ \text { Ibrutinib }+ \\
\quad \text { Obinutuzumab }\end{array}$ & $\begin{array}{l}\text { Bruton tyrosine-kinase inhibitor }+ \\
\text { anti-CD20 antibody }\end{array}$ & 3 & CLL & June 2027 & NCT03737981 \\
\hline $\begin{array}{l}\text { Venetoclax }+ \text { pirtobrutinib }+ \\
\text { rituximab }\end{array}$ & $\begin{array}{l}\text { Bruton tyrosine-kinase inhibitor }+ \\
\text { anti-CD20 antibody }\end{array}$ & 3 & CLL & January 2027 & NCT04965493 \\
\hline $\begin{array}{l}\text { Venetoclax + Ublituximab + } \\
\text { Umbralisib }\end{array}$ & $\begin{array}{l}\text { Anti-CD20 antibody }+ \text { inhibitor of } \\
\text { phosphatidylinositide 3-kinase }\end{array}$ & 3 & CLL & March 2025 & NCT03801525 \\
\hline $\begin{array}{l}\text { Venetoclax }+ \text { Lenalidomide }+ \\
\text { Obinutuzumab }\end{array}$ & $\begin{array}{c}\text { Immunomodulatory agent }+ \text { anti-CD20 } \\
\text { antibody }\end{array}$ & 2 & FL & November 2026 & NCT03980171 \\
\hline $\begin{array}{l}\text { Venetoclax }+ \text { ivosidenib }+/- \\
\text { azacitidine }\end{array}$ & $\begin{array}{l}\text { Inhibitor of isocitrate dehydrogenase } \\
\text { (IDH1) + hypomethylating agent }\end{array}$ & 2 & IDH1-Mutated HM & September 2021 & NCT03471260 \\
\hline Venetoclax + R-CHOP & Standard immunochemotherapy R-CHOP & 2 & Richter syndrome & December 2025 & NCT03054896 \\
\hline $\begin{array}{l}\text { Venetoclax + Carfilzomib and } \\
\text { Dexamethasone }\end{array}$ & Proteasome inhibitor and corticosteroid & 2 & $\mathrm{MM}$ & August 2025 & NCT02899052 \\
\hline Venetoclax + dasatinib & Tyrosine-kinase inhibitor & 2 & Early chronic phase CML & December 2040 & NCT02689440 \\
\hline $\begin{array}{l}\text { Venetoclax }+ \text { Ponatinib + } \\
\text { Decitabine }\end{array}$ & $\begin{array}{l}\text { Tyrosine-kinase inhibitor }+ \\
\text { hypomethylating agent }\end{array}$ & 2 & $\mathrm{Ph}+\mathrm{AML}$, blast-phase CML & September 2024 & NCT04188405 \\
\hline $\begin{array}{c}\text { Venetoclax }+ \text { Low-dose } \\
\text { Homoharringtonine }+ \\
\text { Azacitidine }\end{array}$ & $\begin{array}{l}\text { MCL1 and BCL-XL targeting alkaloid + } \\
\text { hypomethylating agent }\end{array}$ & 2 & AML & March 2024 & NCT04824924 \\
\hline $\begin{array}{l}\text { Venetoclax + Azacitidine + } \\
\text { MBG453 }\end{array}$ & $\begin{array}{l}\text { Hypomethylating agent + TIM-3 immune } \\
\text { check point inhibitor }\end{array}$ & 2 & AML & January 2026 & $\begin{array}{c}\text { NCT04150029 } \\
\text { (STIMULUS-AML1) }\end{array}$ \\
\hline Venetoclax + Ibrutinib & Bruton tyrosine-kinase inhibitor & 2 & WM & June 2029 & NCT04273139 \\
\hline
\end{tabular}


Table 4. Cont.

\begin{tabular}{|c|c|c|c|c|c|}
\hline Agent(s) & $\begin{array}{l}\text { Mode of Action of the Agents Used in } \\
\text { Combination with Venetoclax }\end{array}$ & Study Phase & Target Disease & $\begin{array}{l}\text { Estimated Study } \\
\text { Completion Date }\end{array}$ & $\begin{array}{l}\text { ClinicalTrials.gov Identifier } \\
\text { (Other Identifier) }\end{array}$ \\
\hline $\begin{array}{l}\text { Venetoclax }+ \text { Azacitidine }+ \\
\text { Pevonedistat }\end{array}$ & $\begin{array}{c}\text { Hypomethylating agent }+ \\
\text { NEDD8-activating enzyme inhibitor }\end{array}$ & 2 & AML & March 2024 & NCT04266795 (PEVENAZA) \\
\hline $\begin{array}{c}\text { Venetoclax + Polatuzumab } \\
\text { Vedotin + Rituximab }\end{array}$ & $\begin{array}{l}\text { Anti-CD79-MMAE antibody-drug } \\
\text { conjugate + anti-CD20 antibody }\end{array}$ & 2 & MCL & December 2025 & NCT04659044 \\
\hline $\begin{array}{l}\text { Venetoclax + liposomal } \\
\text { vincristine }\end{array}$ & Anti-mitotic agent & 2 & ALL & April 2021 & NCT03504644 \\
\hline Venetoclax + R-ICE & $\begin{array}{l}\text { Anti-CD20 rituximab + salvage } \\
\text { immunochemotherapy R-ICE }\end{array}$ & 2 & DLBCL & October 2021 & NCT03064867 \\
\hline Venetoclax + Eprenetapopt & Mutant TP53 reactivator & 2 & AML & Juna 2023 & NCT04419389 \\
\hline
\end{tabular}

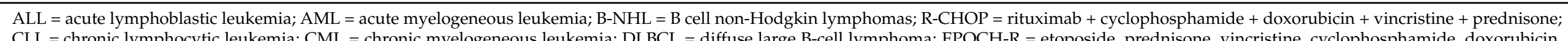

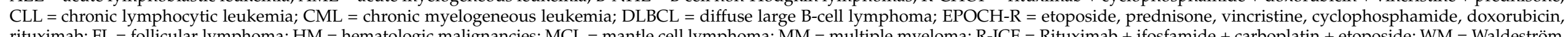

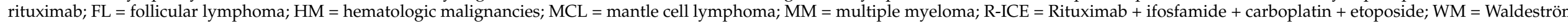
macroglobulinemia. 


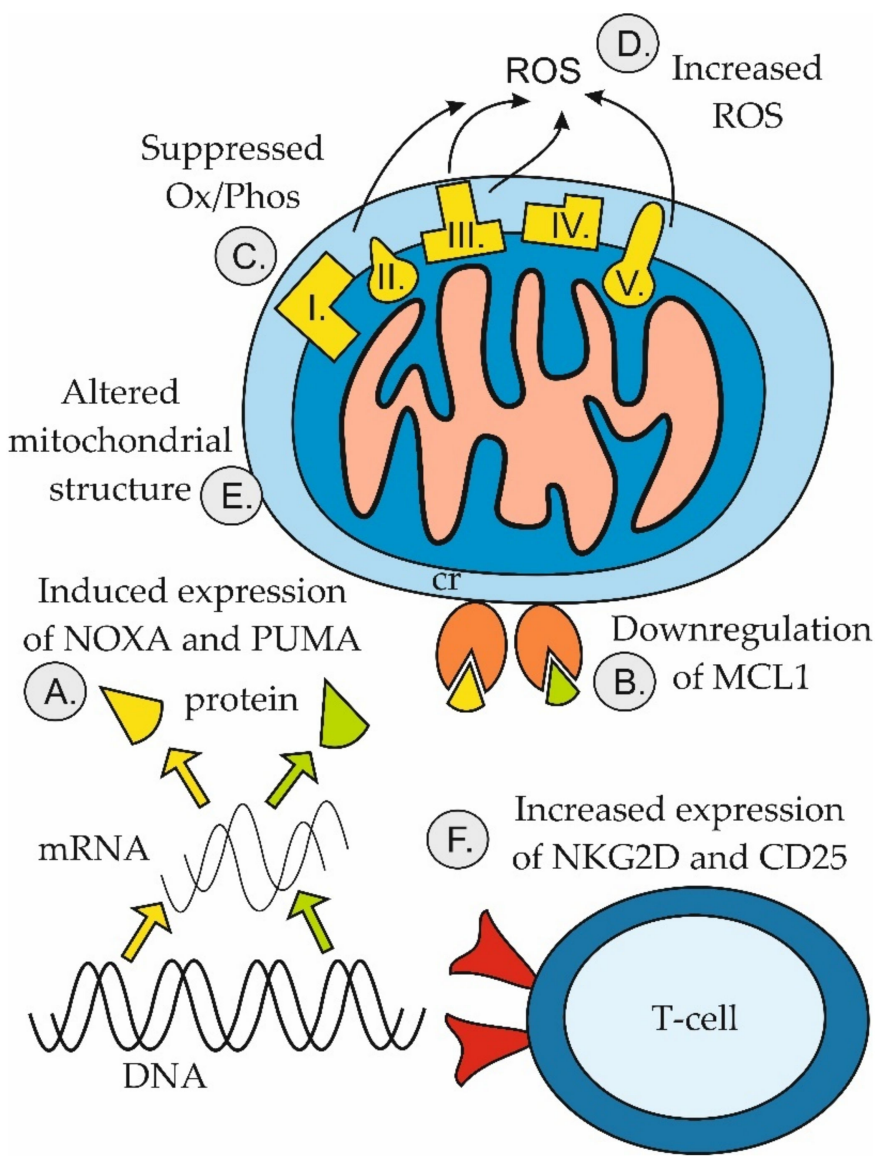

Figure 5. Mechanisms of anti-leukemic synergy between venetoclax and hypomethylating agents. (A) HMA-induced expression of pro-apoptotic genes PMAIP1 (coding for NOXA, yellow) and PUMA (green); (B) HMA-induced downregulation of anti-apoptotic MCL1 protein; (C) Venetoclax-induced suppression of oxidative phosphorylation (Ox/Phos); (D) Venetoclax-mediated increase in production of reactive oxygen species (ROS); (E) Venetoclax-induced alteration of mitochondrial structure; (F) Venetoclax-mediated increase in expression of CD25 and NKG2D on T cells [107,111-113].

Given its anti-tumor mode of action and well-documented single-agent activity across diverse hematologic malignancies, venetoclax is currently being tested in numerous clinical trials in combination with a wide range of targeted agents and conventional cytostatics (Table 4).

Co-targeting BCL2 and MCL1 anti-apoptotic proteins with different BH3 mimetics has shown promise in numerous preclinical studies and is currently being evaluated both preclinically and in several clinical trials [114]. Venetoclax in combination with a Bruton tyrosine kinase inhibitor (ibrutinib, acalabrutinib), with or without an anti-CD20 antibody (rituximab, obinutuzumab) represent other promising innovative (chemotherapy-free) regimens for diverse B-cell malignancies (CLL, MCL, and Waldenström macroglobulinemia) (Table 4) $[115,116]$. Of note, it was demonstrated that ibrutinib and venetoclax target distinct compartments of CLL cells [117]. Such a compartmental synergy represents another form of synthetic lethality, which does not augment anti-tumor efficacy mechanistically within a single malignant cell but which targets different subpopulations of cancer cells residing in specific microenvironmental niches and protected by distinct apoptotic blocks. As demonstrated in the combination of venetoclax and HMA, the synergistic effect may also be mediated by non-malignant cells of the tumor microenvironment, e.g., T-lymphocytes (Figure 5). This phenomenon, however, may be difficult or even impossible to model in vitro using established cell lines, but calls for more complex in vivo models or ex vivo analyses. 


\subsubsection{Next-Generation BCL2 Inhibitors}

Several next-generation BCL2 inhibitors are currently being evaluated in several phase 1 clinical trials assessing their safety and the recommended phase 2 doses (Table 5). S655487 (VOB560) and BGB-11417 are potent and highly selective BCL2 inhibitors with putative activity toward BCL2 mutations (e.g., G101V). APG-2575 demonstrated synthetic lethality with Bruton's tyrosine kinase (BTK) and mouse double minute 2 homolog (MDM2) inhibitors in preclinical models of DLBCL [118].

Table 5. Selected clinical trials that incorporate next-generation BCL2 inhibitors in experimental therapy of hematologic malignancies.

\begin{tabular}{|c|c|c|c|c|c|}
\hline $\begin{array}{l}\text { Next-Generation } \\
\text { BCL2 Inhibitors +/- } \\
\text { Other Agents }\end{array}$ & $\begin{array}{l}\text { Mode of Action of } \\
\text { Agent(s) Used in } \\
\text { Combination with } \\
\text { the Next-Generation } \\
\text { BCL2 Inhibitor }\end{array}$ & Study Phase & Disease Status & $\begin{array}{l}\text { Estimated Study } \\
\text { Completion Date }\end{array}$ & $\begin{array}{l}\text { ClinicalTrials. } \\
\text { gov Identifier } \\
\text { (Other Identifier) }\end{array}$ \\
\hline BGB-11417 & $\begin{array}{l}\text { Single-agent BCL2 } \\
\text { inhibitor }\end{array}$ & 1 & $\begin{array}{l}\text { mature B-cell } \\
\text { malignancies }\end{array}$ & May 2024 & NCT04883957 \\
\hline $\begin{array}{c}\text { BGB-11417 + /- } \\
\text { zanubrutinib }\end{array}$ & $\begin{array}{l}\text { Bruton tyrosine-kinase } \\
\text { inhibitor }\end{array}$ & 1 & $\begin{array}{l}\text { mature B-cell } \\
\text { malignancies }\end{array}$ & August 2023 & NCT04277637 \\
\hline BGB-11417 & $\begin{array}{l}\text { Single-agent BCL2 } \\
\text { inhibitor }\end{array}$ & 1 & $\begin{array}{c}\text { Myeloid } \\
\text { malginancies }\end{array}$ & February 2024 & NCT04771130 \\
\hline $\begin{array}{c}\text { BGB-11417 +/- } \\
\text { Carfilzomib + } \\
\text { Dexamethasone }\end{array}$ & $\begin{array}{l}\text { Proteasome inhibitor + } \\
\text { corticosteroid }\end{array}$ & $1 / 2$ & MM & September 2025 & NCT04973605 \\
\hline S65487 + Azacitidine & $\begin{array}{l}\text { Hypomethylating } \\
\text { agent }\end{array}$ & $1 / 2$ & AML & March 2024 & NCT04742101 \\
\hline S65487 & $\begin{array}{c}\text { Single-agent BCL2 } \\
\text { inhibitor }\end{array}$ & 1 & $\begin{array}{l}\text { AML, B-NHL, } \\
\text { MM, CLL }\end{array}$ & August 2023 & NCT03755154 \\
\hline $\begin{array}{l}\text { S65487/VOB560 + } \\
\text { MIK665/S64315 }\end{array}$ & MCL1 inhibitor & 1 & $\mathrm{HM}$ & January 2025 & NCT04702425 \\
\hline APG-2575 & $\begin{array}{l}\text { Single-agent BCL2 } \\
\text { inhibitor }\end{array}$ & 1 & CLL/SLL & January 2022 & NCT04215809 \\
\hline $\begin{array}{l}\text { APG-2575 + Pomalido- } \\
\text { mide/Dexamethasone } \\
\text { or Daratumumab + } \\
\text { Lenalidomide + } \\
\text { Dexamethasone }\end{array}$ & $\begin{array}{l}\text { Immunomodulatory } \\
\text { agents pomalidomide } \\
\text { and lenalidomide, } \\
\text { anti-CD38 antibody } \\
\text { daratumumab, } \\
\text { corticosteroid } \\
\text { dexamethasone }\end{array}$ & $1 / 2$ & $\mathrm{MM}$ & December 2023 & NCT04942067 \\
\hline $\begin{array}{l}\text { APG-2575 a } \\
\text { Azacitidine }\end{array}$ & $\begin{array}{l}\text { Hypomethylating } \\
\text { agent }\end{array}$ & 1 & AML & October 2023 & NCT04964518 \\
\hline FCN-338 & $\begin{array}{l}\text { Single-agent BCL2 } \\
\text { inhibitor }\end{array}$ & 1 & CLL/SLL & June 2024 & NCT04682808 \\
\hline
\end{tabular}

$\mathrm{AML}=$ acute myelogeneous leukemia; B-NHL = B-cell non-Hodgkin lymphoma; CLL = chronic lymphocytic leukemia; HM = hematologic malignancies; $\mathrm{MM}=$ multiple myeloma; $\mathrm{SLL}=$ small lymphocytic lymphoma.

\section{MCL1}

\subsection{MCL1 and Its Role in the Regulation of Apoptosis and Other Cellular Processes}

Myeloid cell leukemia 1 (MCL1) was discovered as a prosurvival gene expressed during phorbol ester-induced differentiation of ML-1 human myeloid leukemia cell line [119]. Endogenously, MCL1 is transcribed at various stages of hematopoietic cell differentiation in response to specific growth factors and cytokines and its major role is the promotion of cell viability. Conversely, the loss of MCL1 expression results in programmed cell death, 
e.g., MYC-driven apoptosis. As in the case of BCL2, MCL1 can be found not only in the outer mitochondrial membrane but also in the endoplasmic reticulum, nuclear envelope, and in the form of a heterodimer with BAX also in the cytosol $[120,121]$. MCL1 has a similar structure to other anti-apoptotic BCL2 family proteins, with three BH1-3 domains, a putative BH4 domain, and a BH3-binding hydrophobic groove [122]. However, in contrast to the other members of this group, MCL1 contains an extended N-terminal regulatory domain with multiple phosphorylation sites [123,124]. MCL1 is a PEST (P, Pro; E, Glu; S, Ser; $\mathrm{T}, \mathrm{Thr}$ )-containing short-lived protein and its expression is tightly regulated via ubiquitination by E3 ligases such as MCL1 Ubiquitin Ligase E3 (MULE) and by its interaction with the BH3-only protein NOXA [125-127]. In addition to its specific interaction with NOXA, the anti-apoptotic function of MCL1 can be disrupted by other BH-3 only proteins, particularly BIM, BID, and PUMA [10,128]. In contrast to BCL2, MCL1 knockout mice prematurely die during embryogenesis, already at the peri-implantation stage, due to a trophectoderm defect [129]. Conditional, lineage-specific elimination of MCL1 expression during embryogenesis or in the adult mice confirmed a key role of MCL1 in the cardiac homeostasis, the survival of hematopoietic stem cells, lymphocytes, and neural precursors, the development of B-cells, the formation and maintenance of germinal center B-cells, and the development and survival of plasma cells, and naive and memory T cells [130-132]. In addition to the anti-apoptotic function of MCL1, its shorter variant, "MCL1 short" (MCL1-S, $36 \mathrm{kD}$ ), which is localized in the inner mitochondrial membrane, likely participates in mitochondrial physiology and respiration via the stabilization of respiratory complexes and maintenance of cristae [133]. Moreover, MCL1-S interacts with very long-chain acyl-CoA dehydrogenase modulating its activity and, thus, participating in lipid metabolism [134].

\subsection{MCL1 and Hematologic Malignancies}

It has been demonstrated that diverse solid cancers and hematologic malignancies harbor amplifications of the 1q21 region that codes for MCL1 [135,136]. Additionally, it has also been proven that targeted downregulation of the MCL1 gene in the tumors with 1q21 amplification decreases viability of these tumors. Moreover, while BCL2 transgenic mice only develop tumors with a low frequency or after cooperation with other oncogenes (e.g., MYC), MCL1 transgenic mice were shown to develop lymphomas (predominantly FL and DLBCL) with high probability (>80\%), although with a long latency (over 6 months) [22,137]. The critical role of MCL1 during MYC-driven lymphomagenesis and for the continued survival of lymphoma cells has been repeatedly demonstrated [138]. DLBCL, the most prevalent lymphoma subtype, can be divided into BCL2 and MCL1dependent categories [46]. MCL1 was reported to be deregulated in a significant fraction of activated B-cells (ABC) DLBCL [139]. Overexpression of MCL1 is a negative prognostic marker in CLL and AML [140-142]. Burkitt lymphoma (inherently BCL2-negative) and a subset of BCL2-negative DLBCL are strongly dependent on MCL1 for survival. Multiple myeloma with 1q21 amplification is highly sensitive to MCL1 inhibition [143].

\subsection{MCL1 Inhibitors}

Similarly to BCL2, targeting MCL1 effectively eradicates cancer cells irrespective of their TP53 mutational status [144]. Several MCL1 inhibitors are currently being evaluated in clinical trials (Table 6). AZD5991 showed potent anti-tumor activity on animal models of AML and multiple myeloma [145]. Another MCL1 inhibitor, AMG-176, was active in CLL patients, and its combination with low-dose venetoclax proved synergistic [146]. However, it must be stressed that MCL1 inhibition has been associated with significant side effects including cardiotoxicity [147]. The safety profile (not efficacy) will probably be the deciding factor in the future trials evaluating the combined inhibition of BCL2 and MCL1. 
Table 6. Selected clinical trials that incorporate MCL1 inhibitors in experimental therapy of hematologic malignancies.

\begin{tabular}{|c|c|c|c|c|c|}
\hline Agent(s) & $\begin{array}{l}\text { Mode of Action of } \\
\text { Agent(s) Used in } \\
\text { Combination with } \\
\text { the MCL1 Inhibitor }\end{array}$ & Study Phase & Disease Status & $\begin{array}{l}\text { Estimated Study } \\
\text { Completion Date }\end{array}$ & $\begin{array}{c}\text { ClinicalTrials.gov } \\
\text { Identifier (Other } \\
\text { Identifier) }\end{array}$ \\
\hline $\begin{array}{l}\text { AZD5991 + } \\
\text { Venetoclax }\end{array}$ & BCL2 inhibitor & 2 & AML & March 2023 & NCT03218683 \\
\hline $\begin{array}{l}\text { MIK665/S64315 + } \\
\text { Azacytidine }\end{array}$ & $\begin{array}{l}\text { Hypomethylating } \\
\text { agent }\end{array}$ & $1 / 2$ & AML & March 2024 & NCT04629443 \\
\hline $\begin{array}{l}\text { MIK665/S64315 + } \\
\text { VOB560/S65487 }\end{array}$ & BCL2 inhibitor & $1 b$ & $\begin{array}{c}\text { lymphoma, MM, } \\
\text { AML }\end{array}$ & January 2025 & NCT04702425 \\
\hline MIK665/S64315 & $\begin{array}{l}\text { Single-agent MCL1 } \\
\text { inhibitor }\end{array}$ & 1 & $\begin{array}{c}\text { lymphoma, MM, } \\
\text { AML }\end{array}$ & Completed & NCT02992483 \\
\hline PRT1419 & $\begin{array}{l}\text { Single-agent MCL1 } \\
\text { inhibitor }\end{array}$ & 1 & $\begin{array}{l}\text { lymphoma, MM, } \\
\text { AML, MDS }\end{array}$ & September 2022 & NCT04543305 \\
\hline AMG-176 & $\begin{array}{l}\text { Single-agent MCL1 } \\
\text { inhibitor }\end{array}$ & 1 & MM, AML & December 2023 & NCT02675452 \\
\hline $\begin{array}{l}\text { MIK665/S64315 + } \\
\text { Venetoclax }\end{array}$ & BCL2 inhibitor & 1 & AML & January 2024 & NCT03672695 \\
\hline ABBV-467 & $\begin{array}{l}\text { Single-agent MCL1 } \\
\text { inhibitor }\end{array}$ & 1 & MM, AML & Terminated & NCT04178902 \\
\hline $\begin{array}{l}\text { AMG-176 + } \\
\text { Venetoclax }\end{array}$ & BCL2 inhibitor & 1 & R/R HM & Suspended (Safety) & NCT03797261 \\
\hline
\end{tabular}

$\mathrm{AML}=$ acute myelogeneous leukemia; $\mathrm{HM}=$ hematologic malignancies; $\mathrm{MDS}=$ myelodysplastic syndromes; $\mathrm{MM}=$ multiple myeloma.

\subsection{CDK Inhibitors for Targeted MCL1 Inhibition}

As mentioned above, MCL1 is a short-lived anti-apoptotic protein. Consequently, MCL1 inhibition can be effectively achieved not only at the protein level but also transcriptionally. Several CDK inhibitors have been described to effectively suppress mRNA and protein levels of MCL1 [148,149]. Such inhibitors can eliminate MCL1-dependent malignant cells and synergize with venetoclax [148]. CDK7 inhibitor THZ1 was shown to be synthetically lethal with venetoclax in MM through transcriptional downregulation of MCL1, BCL-XL, and MYC [150]. CDK9 inhibitor AZD4573 can overcome intrinsic resistance to venetoclax by inhibiting BCL2BFL-1/A1 in preclinical models of lymphomas [151].

\section{BCL-XL}

\subsection{BCL-XL and Its Role in Regulation of Apoptosis and Other Cellular Processes}

BCL-X, another key regulator of apoptosis, encoded by BCL2L1 gene, exists in two forms: a long form designated BCL-XL, an anti-apoptotic protein with BH1-4 domains, and a shorter variant called BCL-XS lacking BH1 and BH2 domains [152]. BCL-XL was the first identified BCL2 homolog with the highest sequence and a structural similarity to BCL2 [153]. BCL-XL knockout mice prematurely die during embryogenesis due to extensive apoptosis of immature hematopoietic cells and neurons [154]. BCL-XL has a C-terminal hydrophobic helix with a particular mitochondrial signal sequence, which localizes this protein to MOM [155]. Due to the structural flexibility of its binding groove, BCL-XL has a high affinity to all major BH3-only proteins (BIM, BMF, BAD, BIK, HRK, PUMA, BID) as well as to BAX and BAK1 [156,157]. In addition to binding to and preventing allosteric activation of BAX and BAK1, BCL-XL can shuttle BAX to cytosol, thereby reducing its levels in mitochondria [158]. Similarly to BCL2, BCL-XL participates in the modulation of several important non-apoptotic cellular processes including the regulation of ER calcium stores, maintenance of the physiological conformation of VDAC, and promotion of the exchange of metabolites, including ADP, across the MOM [159-161]. BCL-XL can also 
interact with Beclin-1, thereby preventing stress-induced activation of autophagy [162]. Additionally, it participates in the maintenance of the homeostasis of T cells and the survival of hematopoietic stem cells $[163,164]$. Lastly, endogenous BCL-XL is critical for MYC-driven lymphomagenesis in mice [165].

\subsection{BCL-XL and Hematologic Malignancies}

BCL2L1 chromosome region 20q11.21 coding for BCL-XL is amplified in diverse malignancies [136]. In analogy to MCL1-amplified tumors, targeted downregulation of BCL-XL in the tumors with 20q11.21 gains was associated with decreased survival or the induction of programmed cell death. Upregulated BCL-XL correlated with adverse outcome in AML [166]. Recently, BCL-XL has gained attention as one of the principal mediators of venetoclax resistance.

\subsection{BCL-XL Inhibitors}

Despite its well-established role in blocking the apoptotic cascade, specific inhibitors of BCL-XL have shown limited single-agent activity in the experimental therapy of hematologic malignancies [167]. The recent discovery of the essential role of BCL-XL in mediating resistance to venetoclax reestablishes the potential therapeutic role of BCL-XL inhibitors as venetoclax sensitizers [168]. The combination of venetoclax and navitoclax was well tolerated in patients with AML and lymphoblastic lymphomas [169]. Novel, dual BCL2 and BCL-XL inhibitors, e.g., AZD0466 or pelcitoclax (APG-1252), are currently under clinical development [170,171].

\section{BCL-W and BFL-1/A1}

\section{1. $B C L-W$}

In contrast to the three above-mentioned major anti-apoptotic BCL-2 family proteins, the remaining three, i.e., BCL-W, BFL-1/A1, and BCL-B have been much less studied. BCLW was discovered in 1996 and was later also confirmed as an anti-apoptotic BCL-2 family protein similar to BCL-XL, blocking the pro-apoptotic potential of BAX and BAK as well as interacting with multiple members of the BH3-only group [156,172]. BCL-W is expressed in multiple tissues including the testes, colon, brain, and cells of hematopoietic origin. Mice with eliminated expression of BCL-W are viable, though males are infertile due to excessive loss of Sertolli and germ cells [173-175]. Furthermore, BCL-W was reported to contribute to the survival of epithelial cells in the gut and B lymphocytes $[173,176]$. However, increased expression of BCL-W is linked to tumorigenesis in various types of cancers [177]. Among hematologic malignancies, BCL-W is highly expressed in a subset of c-MYC-expressing DLBCL and Burkitt lymphomas as well as B-CLL cells, although it appears dispensable for their survival $[176,178]$. Thus far, no BCL-W-specific BH3 mimetics have been discovered, most likely due to its high conformational flexibility.

\subsection{BFL-1/A1}

Similarly to BCL-W, BFL-1 (human)/A1 (murine) was discovered in 1996 as yet another anti-apoptotic protein from the BCL-2 family. It contains three BH1-3 domains and a glutamine stretch in place of a putative BH4 domain $[179,180]$. Even though A1 is expressed in multiple mouse embryonic tissues, its genetic elimination causes only a minor defect in dendritic cell survival, while its shRNA-mediated downregulation in vivo impairs T cell differentiation and granulocyte survival [181,182]. Interestingly, A1 enhances BCL-2 and MCL-1 mediated survival of hematopoietic cells and its expression can be activated by inflammatory cytokines TNF- $\alpha$ and IL-1- $\beta$, likely in an NF- $\kappa$ B-dependent manner $[183,184]$. BFL-1/A1 is overexpressed in therapy-resistant lymphoma cell lines, and its expression enhances the survival of c-MYC-dependent B-cell lymphomas and EBV LMP1 proteinexpressing Burkitt lymphoma [185-188]. Moreover, overexpression of BFL-1 enhances the resistance of c-MYC- and BCL2-expressing double-hit lymphomas to venetoclax, while its downregulation sensitizes them to apoptotic stimuli $[189,190]$. Simultaneous expression 
downregulation of two anti-apoptotic BCL2 proteins with short half-lives, BFL-1/A1 and MCL1, by CDK9 inhibitors has been shown to overcome the resistance of DLBCL cells to venetoclax $[151,190]$. These preclinical data provide a clear rationale for the potential of BFL-1/A1-targeting BH3 mimetics in the experimental therapy of cancer [191].

\subsection{Disadvantages of BH3 Mimetics}

BH3 mimetics belong to targeted anti-cancer agents. Consequently, their anti-tumor efficacy depends upon the expression of their respective targets, the anti-apoptotic BCL2 proteins. In translation, all BCL2-negative malignancies (e.g., Burkitt lymphoma, BCL2negative DLBCL, or a substantial part of MM) are inherently "resistant" to BCL2 inhibition with venetoclax but still may be effectively targeted with other BH3 mimetics, e.g., MCL1 inhibitors. Importantly, for the full deployment of their pro-apoptotic activity, the antiapoptotic BCL2 proteins must be primed for death, or "loaded" with pro-apoptotic BH3only proteins, and the effectors of the apoptotic pathway must remain functional $[4,192]$. Leukemia or lymphoma cells with mutated BAX, or BCL2 protein not primed for death, will not respond to venetoclax. Currently, there are few reliable predictive markers of the sensitivity to venetoclax or other BH3 mimetics. Techniques such as (dynamic) BH3 profiling remain limited to a few highly specialized translational laboratories and cannot be considered a standard diagnostic procedure [193,194]. Lastly, the current standard of long-term dosing of venetoclax may be associated with cumulative toxic side effects. The long-term exposure of leukemia stem cells or lymphoma "persister cells" to venetoclax may lead to the development of the above-described adaptive changes and relapse of the resistant disease.

\section{Conclusions}

BH3 mimetics represent innovative molecules that have proved effective both individually and in combination with a diverse group of conventional, targeted, or biological anti-tumor agents in various types of hematologic malignancies. Their capability to induce BAX/BAK1-dependent apoptosis without requiring the activation of canonical DNA damage pathways enables the eradication of non-dividing malignant cells with complex karyotypic alterations, defects in TP53, and inactivation of other key tumor suppressor genes. Besides their well-described mechanistic pro-apoptotic activities, recent data have brought evidence of important non-canonical anti-tumor functions, namely modulation of oxidative phosphorylation and other vital mitochondrial functions. The frequent development of resistance to venetoclax monotherapy (and, preclinically, to other single-agent $\mathrm{BH} 3$ mimetics) calls for novel, more effective treatment combinations. Alternatively, $\mathrm{BH} 3$ mimetics might be used in sequential protocols for the targeted eradication of minimal residual disease following debulking with standard regimens. The currently running clinical trials that incorporate venetoclax and next-generation $\mathrm{BH} 3$ mimetics will soon shed light not only on the efficacy of these experimental regimens but also on other critical aspects associated with $\mathrm{BH} 3$ mimetic treatments, including safety issues, the optimal length of therapy, and reliable biomarkers of sensitivity or resistance.

Funding: The manuscript was supported by the Ministry of Health of the Czech Republic grant AZV NU21-03-00386, all rights reserved, Grant Agency of the Czech Republic GA20-25308S, and 19-08772S Charles University Center of Excellence UNCE/MED/016, and Ministry of Education, Youth and Sports grants PROGRES Q26/LF1 and PROGRES Q28/LF1.

Conflicts of Interest: The authors declare no conflict of interest. 


$\begin{array}{ll}\text { Abbreviations } & \\ \text { ABC } & \text { Activated B-Cell } \\ \text { AL (amyloidosis) } & \text { Amyloid Light (chain) } \\ \text { AML } & \text { Acute Myeloid Leukemia } \\ \text { BCL2 } & \text { B-cell Lymphoma 2 } \\ \text { BH3 } & \text { BCL2 Homology 3 } \\ \text { BTK } & \text { Bruton's Tyrosine Kinase } \\ \text { CDK } & \text { Cyclin-Dependent Kinase } \\ \text { CLL } & \text { Chronic Lymphocytic Leukemia } \\ \text { DLBCL } & \text { Diffuse Large B-cell Lymphoma } \\ \text { ER } & \text { Endoplasmic Reticulum } \\ \text { GCB } & \text { Germinal Center B-cell } \\ \text { HM } & \text { Hematologic Malignancies } \\ \text { HMA } & \text { Hypomethylating Agents } \\ \text { MCL } & \text { Mantle Cell Lymphoma } \\ \text { MCL1 } & \text { Myeloid Cell Leukemia 1 } \\ \text { MDM2 } & \text { Mouse Double Minute 2 Homologue } \\ \text { MM } & \text { Multiple Myeloma } \\ \text { MOM } & \text { Mitochondria Outer Membrane } \\ \text { OxPhos } & \text { Oxidative Phosphorylation } \\ \text { TM } & \text { Transmembrane Domain } \\ \text { RCD } & \text { Regulated Cell Death } \\ \text { R-CHOP } & \text { Rituximab + Cyclophosphamide + Hydroxydaunomycin + Oncovin + Prednisone } \\ \text { ROS } & \text { Reactive Oxygen Species } \\ \text { R/R } & \text { Relapsed/Refractory } \\ & \end{array}$

\section{References}

1. Nagata, S. Apoptosis and clearance of apoptotic cells. Annu. Rev. Immunol. 2018, 36, 489-517. [CrossRef] [PubMed]

2. Ramirez, M.L.G.; Salvesen, G.S. A primer on caspase mechanisms. Semin. Cell Dev. Biol. 2018, 82, 79-85. [CrossRef]

3. Van Opdenbosch, N.; Lamkanfi, M. Caspases in cell death, inflammation, and disease. Immunity 2019, 50, 1352-1364. [CrossRef] [PubMed]

4. Certo, M.; Del Gaizo Moore, V.; Nishino, M.; Wei, G.; Korsmeyer, S.; Armstrong, S.A.; Letai, A. Mitochondria primed by death signals determine cellular addiction to antiapoptotic BCL-2 family members. Cancer Cell 2006, 9, 351-365. [CrossRef]

5. Carneiro, B.A.; El-Deiry, W.S. Targeting apoptosis in cancer therapy. Nat. Rev. Clin. Oncol. 2020, 17, 395-417. [CrossRef]

6. Leveille, E.; Johnson, N.A. Genetic events inhibiting apoptosis in diffuse large B cell lymphoma. Cancers 2021, 13, 2167. [CrossRef]

7. Hanahan, D.; Weinberg, R.A. Hallmarks of cancer: The next generation. Cell 2011, 144, 646-674. [CrossRef]

8. Adams, J.M.; Cory, S. The BCL-2 arbiters of apoptosis and their growing role as cancer targets. Cell Death Differ. 2018, 25, 27-36. [CrossRef]

9. Glab, J.A.; Mbogo, G.W.; Puthalakath, H. BH3-only proteins in health and disease. Int. Rev. Cell Mol. Biol. 2017, 328, 163-196. [CrossRef]

10. Chen, L.; Willis, S.N.; Wei, A.; Smith, B.J.; Fletcher, J.I.; Hinds, M.G.; Colman, P.M.; Day, C.L.; Adams, J.M.; Huang, D.C. Differential targeting of prosurvival Bcl-2 proteins by their BH3-only ligands allows complementary apoptotic function. Mol. Cell 2005, 17, 393-403. [CrossRef]

11. Reed, J.C. Bcl-2 family proteins. Oncogene 1998, 17, 3225-3236. [CrossRef]

12. Chi, X.; Nguyen, D.; Pemberton, J.M.; Osterlund, E.J.; Liu, Q.; Brahmbhatt, H.; Zhang, Z.; Lin, J.; Leber, B.; Andrews, D.W. The carboxyl-terminal sequence of bim enables bax activation and killing of unprimed cells. Elife 2020, 9. [CrossRef]

13. Ye, K.; Meng, W.X.; Sun, H.; Wu, B.; Chen, M.; Pang, Y.P.; Gao, J.; Wang, H.; Wang, J.; Kaufmann, S.H.; et al. Characterization of an alternative BAK-binding site for BH3 peptides. Nat. Commun. 2020, 11, 3301. [CrossRef] [PubMed]

14. Dengler, M.A.; Robin, A.Y.; Gibson, L.; Li, M.X.; Sandow, J.J.; Iyer, S.; Webb, A.I.; Westphal, D.; Dewson, G.; Adams, J.M. BAX activation: Mutations near its proposed non-canonical $\mathrm{BH} 3$ binding site reveal allosteric changes controlling mitochondrial association. Cell Rep. 2019, 27, 359-373.e6. [CrossRef]

15. Kale, J.; Osterlund, E.J.; Andrews, D.W. BCL-2 family proteins: Changing partners in the dance towards death. Cell Death Differ. 2018, 25, 65-80. [CrossRef] [PubMed]

16. Ichim, G.; Lopez, J.; Ahmed, S.U.; Muthalagu, N.; Giampazolias, E.; Delgado, M.E.; Haller, M.; Riley, J.S.; Mason, S.M.; Athineos, D.; et al. Limited mitochondrial permeabilization causes DNA damage and genomic instability in the absence of cell death. Mol. Cell 2015, 57, 860-872. [CrossRef]

17. Fukuhara, S.; Rowley, J.D.; Variakojis, D.; Golomb, H.M. Chromosome abnormalities in poorly differentiated lymphocytic lymphoma. Cancer Res. 1979, 39, 3119-3128. 
18. Tsujimoto, Y.; Finger, L.R.; Yunis, J.; Nowell, P.C.; Croce, C.M. Cloning of the chromosome breakpoint of neoplastic B cells with the $\mathrm{t}(14 ; 18)$ chromosome translocation. Science 1984, 226, 1097-1099. [CrossRef] [PubMed]

19. Tsujimoto, Y.; Croce, C.M. Analysis of the structure, transcripts, and protein products of bcl-2, the gene involved in human follicular lymphoma. Proc. Natl. Acad. Sci. USA 1986, 83, 5214-5218. [CrossRef]

20. Hockenbery, D.; Nuñez, G.; Milliman, C.; Schreiber, R.D.; Korsmeyer, S.J. Bcl-2 is an inner mitochondrial membrane protein that blocks programmed cell death. Nature 1990, 348, 334-336. [CrossRef] [PubMed]

21. Strasser, A.; Harris, A.W.; Bath, M.L.; Cory, S. Novel primitive lymphoid tumours induced in transgenic mice by cooperation between myc and bcl-2. Nature 1990, 348, 331-333. [CrossRef]

22. Vaux, D.L.; Cory, S.; Adams, J.M. Bcl-2 gene promotes haemopoietic cell survival and cooperates with c-myc to immortalize pre-B cells. Nature 1988, 335, 440-442. [CrossRef]

23. McDonnell, T.J.; Deane, N.; Platt, F.M.; Nunez, G.; Jaeger, U.; McKearn, J.P.; Korsmeyer, S.J. bcl-2-immunoglobulin transgenic mice demonstrate extended B cell survival and follicular lymphoproliferation. Cell 1989, 57, 79-88. [CrossRef]

24. Zheng, J.H.; Viacava Follis, A.; Kriwacki, R.W.; Moldoveanu, T. Discoveries and controversies in BCL-2 protein-mediated apoptosis. FEBS J. 2016, 283, 2690-2700. [CrossRef]

25. Krajewski, S.; Tanaka, S.; Takayama, S.; Schibler, M.J.; Fenton, W.; Reed, J.C. Investigation of the subcellular distribution of the bcl-2 oncoprotein: Residence in the nuclear envelope, endoplasmic reticulum, and outer mitochondrial membranes. Cancer Res. 1993, 53, 4701-4714.

26. Veis, D.J.; Sorenson, C.M.; Shutter, J.R.; Korsmeyer, S.J. Bcl-2-deficient mice demonstrate fulminant lymphoid apoptosis, polycystic kidneys, and hypopigmented hair. Cell 1993, 75, 229-240. [CrossRef]

27. Nakayama, K.; Nakayama, K.; Negishi, I.; Kuida, K.; Shinkai, Y.; Louie, M.C.; Fields, L.E.; Lucas, P.J.; Stewart, V.; Alt, F.W.; et al. Disappearance of the lymphoid system in Bcl-2 homozygous mutant chimeric mice. Science 1993, 261, 1584-1588. [CrossRef] [PubMed]

28. Bouillet, P.; Cory, S.; Zhang, L.C.; Strasser, A.; Adams, J.M. Degenerative disorders caused by Bcl-2 deficiency prevented by loss of its BH3-only antagonist Bim. Dev. Cell 2001, 1, 645-653. [CrossRef]

29. Gross, A.; Katz, S.G. Non-apoptotic functions of BCL-2 family proteins. Cell Death Differ. 2017, 24, 1348-1358. [CrossRef] [PubMed]

30. Morris, J.L.; Gillet, G.; Prudent, J.; Popgeorgiev, N. Bcl-2 family of proteins in the control of mitochondrial calcium signalling: An old chap with new roles. Int. J. Mol. Sci. 2021, 22, 3730. [CrossRef] [PubMed]

31. Lewis, A.; Hayashi, T.; Su, T.P.; Betenbaugh, M.J. Bcl-2 family in inter-organelle modulation of calcium signaling; Roles in bioenergetics and cell survival. J. Bioenerg. Biomembr. 2014, 46, 1-15. [CrossRef]

32. Vervliet, T.; Clerix, E.; Seitaj, B.; Ivanova, H.; Monaco, G.; Bultynck, G. Modulation of Ca ${ }^{2+}$ signaling by anti-apoptotic B-cell lymphoma 2 proteins at the endoplasmic reticulum-mitochondrial interface. Front. Oncol. 2017, 7, 75. [CrossRef] [PubMed]

33. Janumyan, Y.M.; Sansam, C.G.; Chattopadhyay, A.; Cheng, N.; Soucie, E.L.; Penn, L.Z.; Andrews, D.; Knudson, C.M.; Yang, E. $\mathrm{Bcl}-\mathrm{xL} / \mathrm{Bcl}-2$ coordinately regulates apoptosis, cell cycle arrest and cell cycle entry. EMBO J. 2003, 22, 5459-5470. [CrossRef]

34. O'Reilly, L.A.; Huang, D.C.; Strasser, A. The cell death inhibitor Bcl-2 and its homologues influence control of cell cycle entry. EMBO J. 1996, 15, 6979-6990. [CrossRef] [PubMed]

35. Chen, Z.X.; Pervaiz, S. Involvement of cytochrome c oxidase subunits $\mathrm{Va}$ and $\mathrm{Vb}$ in the regulation of cancer cell metabolism by Bcl-2. Cell Death Differ. 2010, 17, 408-420. [CrossRef]

36. Manfredi, G.; Kwong, J.Q.; Oca-Cossio, J.A.; Woischnik, M.; Gajewski, C.D.; Martushova, K.; D’Aurelio, M.; Friedlich, A.L.; Moraes, C.T. BCL-2 improves oxidative phosphorylation and modulates adenine nucleotide translocation in mitochondria of cells harboring mutant mtDNA. J. Biol. Chem. 2003, 278, 5639-5645. [CrossRef] [PubMed]

37. Schuetz, J.M.; Johnson, N.A.; Morin, R.D.; Scott, D.W.; Tan, K.; Ben-Nierah, S.; Boyle, M.; Slack, G.W.; Marra, M.A.; Connors, J.M.; et al. BCL2 mutations in diffuse large B-cell lymphoma. Leukemia 2012, 26, 1383-1390. [CrossRef] [PubMed]

38. Iqbal, J.; Sanger, W.G.; Horsman, D.E.; Rosenwald, A.; Pickering, D.L.; Dave, B.; Dave, S.; Xiao, L.; Cao, K.; Zhu, Q.; et al. BCL2 translocation defines a unique tumor subset within the germinal center B-cell-like diffuse large B-cell lymphoma. Am. J. Pathol. 2004, 165, 159-166. [CrossRef]

39. Saito, M.; Novak, U.; Piovan, E.; Basso, K.; Sumazin, P.; Schneider, C.; Crespo, M.; Shen, Q.; Bhagat, G.; Califano, A.; et al. BCL6 suppression of BCL2 via Miz1 and its disruption in diffuse large B cell lymphoma. Proc. Natl. Acad. Sci. USA 2009, 106, 11294-11299. [CrossRef]

40. Dierlamm, J.; Murga Penas, E.M.; Bentink, S.; Wessendorf, S.; Berger, H.; Hummel, M.; Klapper, W.; Lenze, D.; Rosenwald, A.; Haralambieva, E.; et al. Gain of chromosome region 18q21 including the MALT1 gene is associated with the activated B-cell-like gene expression subtype and increased BCL2 gene dosage and protein expression in diffuse large B-cell lymphoma. Haematologica 2008, 93, 688-696. [CrossRef]

41. Beltran, E.; Fresquet, V.; Martinez-Useros, J.; Richter-Larrea, J.A.; Sagardoy, A.; Sesma, I.; Almada, L.L.; Montes-Moreno, S.; Siebert, R.; Gesk, S.; et al. A cyclin-D1 interaction with BAX underlies its oncogenic role and potential as a therapeutic target in mantle cell lymphoma. Proc. Natl. Acad. Sci. USA 2011, 108, 12461-12466. [CrossRef] [PubMed]

42. Malarikova, D.; Berkova, A.; Obr, A.; Blahovcova, P.; Svaton, M.; Forsterova, K.; Kriegova, E.; Prihodova, E.; Pavlistova, L.; Petrackova, A.; et al. Concurrent TP53 and CDKN2A gene aberrations in newly diagnosed mantle cell lymphoma correlate with chemoresistance and call for innovative upfront therapy. Cancers 2020, 12, 2120. [CrossRef] [PubMed] 
43. Cimmino, A.; Calin, G.A.; Fabbri, M.; Iorio, M.V.; Ferracin, M.; Shimizu, M.; Wojcik, S.E.; Aqeilan, R.I.; Zupo, S.; Dono, M.; et al. miR-15 and miR-16 induce apoptosis by targeting BCL2. Proc. Natl. Acad. Sci. USA 2005, 102, 13944-13949. [CrossRef]

44. Pekarsky, Y.; Balatti, V.; Croce, C.M. BCL2 and miR-15/16: From gene discovery to treatment. Cell Death Differ. 2018, 25, 21-26. [CrossRef] [PubMed]

45. Touzeau, C.; Dousset, C.; Le Gouill, S.; Sampath, D.; Leverson, J.D.; Souers, A.J.; Maïga, S.; Béné, M.C.; Moreau, P.; PellatDeceunynck, C.; et al. The Bcl-2 specific BH3 mimetic ABT-199: A promising targeted therapy for t(11;14) multiple myeloma. Leukemia 2014, 28, 210-212. [CrossRef]

46. Klanova, M.; Andera, L.; Brazina, J.; Svadlenka, J.; Benesova, S.; Soukup, J.; Prukova, D.; Vejmelkova, D.; Jaksa, R.; Helman, K.; et al. Targeting of BCL2 family proteins with ABT-199 and homoharringtonine reveals BCL2- and MCL1-dependent subgroups of diffuse large B-cell lymphoma. Clin. Cancer Res. Off. J. Am. Assoc. Cancer Res. 2015. [CrossRef]

47. Ewald, L.; Dittmann, J.; Vogler, M.; Fulda, S. Side-by-side comparison of BH3-mimetics identifies MCL-1 as a key therapeutic target in AML. Cell Death Dis. 2019, 10, 917. [CrossRef] [PubMed]

48. Zhou, J.D.; Zhang, T.J.; Xu, Z.J.; Gu, Y.; Ma, J.C.; Li, X.X.; Guo, H.; Wen, X.M.; Zhang, W.; Yang, L.; et al. BCL2 overexpression: Clinical implication and biological insights in acute myeloid leukemia. Diagn. Pathol. 2019, 14, 68. [CrossRef] [PubMed]

49. Mehta, S.V.; Shukla, S.N.; Vora, H.H. Overexpression of Bcl2 protein predicts chemoresistance in acute myeloid leukemia: Its correlation with FLT3. Neoplasma 2013, 60, 666-675. [CrossRef]

50. Haes, I.; Dendooven, A.; Mercier, M.L.; Puylaert, P.; Vermeulen, K.; Kockx, M.; Deiteren, K.; Maes, M.B.; Berneman, Z.; Anguille, $\mathrm{S}$. Absence of BCL-2 expression identifies a subgroup of AML with distinct phenotypic, molecular, and clinical characteristics. J. Clin. Med. 2020, 9, 3090. [CrossRef]

51. Tsuyama, N.; Sakata, S.; Baba, S.; Mishima, Y.; Nishimura, N.; Ueda, K.; Yokoyama, M.; Terui, Y.; Hatake, K.; Kitagawa, M.; et al. BCL2 expression in DLBCL: Reappraisal of immunohistochemistry with new criteria for therapeutic biomarker evaluation. Blood 2017, 130, 489-500. [CrossRef]

52. Döhner, H.; Stilgenbauer, S.; Benner, A.; Leupolt, E.; Kröber, A.; Bullinger, L.; Döhner, K.; Bentz, M.; Lichter, P. Genomic aberrations and survival in chronic lymphocytic leukemia. N. Engl. J. Med. 2000, 343, 1910-1916. [CrossRef]

53. Campos, L.; Rouault, J.P.; Sabido, O.; Oriol, P.; Roubi, N.; Vasselon, C.; Archimbaud, E.; Magaud, J.P.; Guyotat, D. High expression of bcl-2 protein in acute myeloid leukemia cells is associated with poor response to chemotherapy. Blood 1993, 81, 3091-3096. [CrossRef]

54. Iqbal, J.; Neppalli, V.T.; Wright, G.; Dave, B.J.; Horsman, D.E.; Rosenwald, A.; Lynch, J.; Hans, C.P.; Weisenburger, D.D.; Greiner, T.C.; et al. BCL2 expression is a prognostic marker for the activated B-cell-like type of diffuse large B-cell lymphoma. J. Clin. Oncol. 2006, 24, 961-968. [CrossRef] [PubMed]

55. Iqbal, J.; Meyer, P.N.; Smith, L.M.; Johnson, N.A.; Vose, J.M.; Greiner, T.C.; Connors, J.M.; Staudt, L.M.; Rimsza, L.; Jaffe, E.; et al. BCL2 predicts survival in germinal center B-cell-like diffuse large B-cell lymphoma treated with CHOP-like therapy and rituximab. Clin. Cancer Res. Off. J. Am. Assoc. Cancer Res. 2011, 17, 7785-7795. [CrossRef] [PubMed]

56. Walker, A.R.; Marcucci, G.; Yin, J.; Blum, W.; Stock, W.; Kohlschmidt, J.; Mrózek, K.; Carroll, A.J.; Eisfeld, A.K.; Wang, E.S.; et al. Phase 3 randomized trial of chemotherapy with or without oblimersen in older AML patients: CALGB 10201 (Alliance). Blood Adv. 2021, 5, 2775-2787. [CrossRef]

57. Chanan-Khan, A.A.; Niesvizky, R.; Hohl, R.J.; Zimmerman, T.M.; Christiansen, N.P.; Schiller, G.J.; Callander, N.; Lister, J.; Oken, M.; Jagannath, S. Phase III randomised study of dexamethasone with or without oblimersen sodium for patients with advanced multiple myeloma. Leuk. Lymphoma 2009, 50, 559-565. [CrossRef] [PubMed]

58. O'Brien, S.M.; Claxton, D.F.; Crump, M.; Faderl, S.; Kipps, T.; Keating, M.J.; Viallet, J.; Cheson, B.D. Phase I study of obatoclax mesylate (GX15-070), a small molecule pan-Bcl-2 family antagonist, in patients with advanced chronic lymphocytic leukemia. Blood 2009, 113, 299-305. [CrossRef] [PubMed]

59. Merino, D.; Kelly, G.L.; Lessene, G.; Wei, A.H.; Roberts, A.W.; Strasser, A. BH3-mimetic drugs: Blazing the trail for new cancer medicines. Cancer Cell 2018, 34, 879-891. [CrossRef]

60. Roberts, A.W.; Seymour, J.F.; Brown, J.R.; Wierda, W.G.; Kipps, T.J.; Khaw, S.L.; Carney, D.A.; He, S.Z.; Huang, D.C.; Xiong, H.; et al. Substantial susceptibility of chronic lymphocytic leukemia to BCL2 inhibition: Results of a phase I study of navitoclax in patients with relapsed or refractory disease. J. Clin. Oncol. Off. J. Am. Soc. Clin. Oncol. 2012, 30, 488-496. [CrossRef] [PubMed]

61. Wilson, W.H.; O'Connor, O.A.; Czuczman, M.S.; LaCasce, A.S.; Gerecitano, J.F.; Leonard, J.P.; Tulpule, A.; Dunleavy, K.; Xiong, H.; Chiu, Y.L.; et al. Navitoclax, a targeted high-affinity inhibitor of BCL-2, in lymphoid malignancies: A phase 1 dose-escalation study of safety, pharmacokinetics, pharmacodynamics, and antitumour activity. Lancet Oncol. 2010, 11, 1149-1159. [CrossRef]

62. Tse, C.; Shoemaker, A.R.; Adickes, J.; Anderson, M.G.; Chen, J.; Jin, S.; Johnson, E.F.; Marsh, K.C.; Mitten, M.J.; Nimmer, P.; et al. ABT-263: A potent and orally bioavailable Bcl-2 family inhibitor. Cancer Res. 2008, 68, 3421-3428. [CrossRef]

63. Oltersdorf, T.; Elmore, S.W.; Shoemaker, A.R.; Armstrong, R.C.; Augeri, D.J.; Belli, B.A.; Bruncko, M.; Deckwerth, T.L.; Dinges, J.; Hajduk, P.J.; et al. An inhibitor of Bcl-2 family proteins induces regression of solid tumours. Nature 2005, 435, 677-681. [CrossRef]

64. Kotschy, A.; Szlavik, Z.; Murray, J.; Davidson, J.; Maragno, A.L.; Le Toumelin-Braizat, G.; Chanrion, M.; Kelly, G.L.; Gong, J.N.; Moujalled, D.M.; et al. The MCL1 inhibitor S63845 is tolerable and effective in diverse cancer models. Nature 2016, 538, 477-482. [CrossRef] [PubMed] 
65. Souers, A.J.; Leverson, J.D.; Boghaert, E.R.; Ackler, S.L.; Catron, N.D.; Chen, J.; Dayton, B.D.; Ding, H.; Enschede, S.H.; Fairbrother, W.J.; et al. ABT-199, a potent and selective BCL-2 inhibitor, achieves antitumor activity while sparing platelets. Nat. Med. 2013, 19, 202-208. [CrossRef] [PubMed]

66. Lessene, G.; Czabotar, P.E.; Sleebs, B.E.; Zobel, K.; Lowes, K.N.; Adams, J.M.; Baell, J.B.; Colman, P.M.; Deshayes, K.; Fairbrother, W.J.; et al. Structure-guided design of a selective BCL-X(L) inhibitor. Nat. Chem. Biol. 2013, 9, 390-397. [CrossRef] [PubMed]

67. Leverson, J.D.; Phillips, D.C.; Mitten, M.J.; Boghaert, E.R.; Diaz, D.; Tahir, S.K.; Belmont, L.D.; Nimmer, P.; Xiao, Y.; Ma, X.M.; et al. Exploiting selective BCL-2 family inhibitors to dissect cell survival dependencies and define improved strategies for cancer therapy. Sci. Transl. Med. 2015, 7, 279ra240. [CrossRef] [PubMed]

68. Tao, Z.F.; Hasvold, L.; Wang, L.; Wang, X.; Petros, A.M.; Park, C.H.; Boghaert, E.R.; Catron, N.D.; Chen, J.; Colman, P.M.; et al. Discovery of a potent and selective BCL-XL inhibitor with in vivo activity. ACS Med. Chem. Lett. 2014, 5, 1088-1093. [CrossRef] [PubMed]

69. Ashkenazi, A.; Fairbrother, W.J.; Leverson, J.D.; Souers, A.J. From basic apoptosis discoveries to advanced selective BCL-2 family inhibitors. Nat. Rev. Drug Discov. 2017, 16, 273-284. [CrossRef]

70. Krishna, S.; Kumar, S.B.; Murthy, T.P.K.; Murahari, M. Structure-based design approach of potential BCL-2 inhibitors for cancer chemotherapy. Comput. Biol. Med. 2021, 134, 104455. [CrossRef]

71. Roberts, A.W.; Davids, M.S.; Pagel, J.M.; Kahl, B.S.; Puvvada, S.D.; Gerecitano, J.F.; Kipps, T.J.; Anderson, M.A.; Brown, J.R.; Gressick, L.; et al. Targeting BCL2 with venetoclax in relapsed chronic lymphocytic leukemia. N. Engl. J. Med. 2016, 374, 311-322. [CrossRef]

72. Jones, J.A.; Mato, A.R.; Wierda, W.G.; Davids, M.S.; Choi, M.; Cheson, B.D.; Furman, R.R.; Lamanna, N.; Barr, P.M.; Zhou, L.; et al. Venetoclax for chronic lymphocytic leukaemia progressing after ibrutinib: An interim analysis of a multicentre, open-label, phase 2 trial. Lancet Oncol. 2018, 19, 65-75. [CrossRef]

73. Stilgenbauer, S.; Eichhorst, B.; Schetelig, J.; Coutre, S.; Seymour, J.F.; Munir, T.; Puvvada, S.D.; Wendtner, C.M.; Roberts, A.W.; Jurczak, W.; et al. Venetoclax in relapsed or refractory chronic lymphocytic leukaemia with 17p deletion: A multicentre, open-label, phase 2 study. Lancet Oncol. 2016, 17, 768-778. [CrossRef]

74. Fischer, K.; Al-Sawaf, O.; Bahlo, J.; Fink, A.M.; Tandon, M.; Dixon, M.; Robrecht, S.; Warburton, S.; Humphrey, K.; Samoylova, O.; et al. Venetoclax and obinutuzumab in patients with CLL and coexisting conditions. N. Engl. J. Med. 2019, 380, 2225-2236. [CrossRef] [PubMed]

75. Al-Sawaf, O.; Zhang, C.; Tandon, M.; Sinha, A.; Fink, A.M.; Robrecht, S.; Samoylova, O.; Liberati, A.M.; Pinilla-Ibarz, J.; Opat, S.; et al. Venetoclax plus obinutuzumab versus chlorambucil plus obinutuzumab for previously untreated chronic lymphocytic leukaemia (CLL14): Follow-up results from a multicentre, open-label, randomised, phase 3 trial. Lancet Oncol. 2020, 21, 1188-1200. [CrossRef]

76. Davids, M.S.; Roberts, A.W.; Seymour, J.F.; Pagel, J.M.; Kahl, B.S.; Wierda, W.G.; Puvvada, S.; Kipps, T.J.; Anderson, M.A.; Salem, A.H.; et al. Phase I first-in-human study of venetoclax in patients with relapsed or refractory non-hodgkin lymphoma. J. Clin. Oncol. Off. J. Am. Soc. Clin. Oncol. 2017, 35, 826-833. [CrossRef] [PubMed]

77. Premkumar, V.J.; Lentzsch, S.; Pan, S.; Bhutani, D.; Richter, J.; Jagannath, S.; Liedtke, M.; Jaccard, A.; Wechalekar, A.D.; Comenzo, R.; et al. Venetoclax induces deep hematologic remissions in $\mathrm{t}(11 ; 14)$ relapsed/refractory AL amyloidosis. Blood Cancer J. 2021, 11, 10. [CrossRef]

78. Kitadate, A.; Terao, T.; Narita, K.; Ikeda, S.; Takahashi, Y.; Tsushima, T.; Miura, D.; Takeuchi, M.; Takahashi, N.; Matsue, K. Multiple myeloma with $\mathrm{t}(11 ; 14)$-associated immature phenotype has lower CD38 expression and higher BCL2 dependence. Cancer Sci. 2021. [CrossRef] [PubMed]

79. Morschhauser, F.; Feugier, P.; Flinn, I.W.; Gasiorowski, R.; Greil, R.; Illés, Á.; Johnson, N.A.; Larouche, J.F.; Lugtenburg, P.J.; Patti, C.; et al. A phase 2 study of venetoclax plus R-CHOP as first-line treatment for patients with diffuse large B-cell lymphoma. Blood 2021, 137, 600-609. [CrossRef] [PubMed]

80. Zelenetz, A.D.; Salles, G.; Mason, K.D.; Casulo, C.; Le Gouill, S.; Sehn, L.H.; Tilly, H.; Cartron, G.; Chamuleau, M.E.D.; Goy, A.; et al. Venetoclax plus R- or G-CHOP in non-Hodgkin lymphoma: Results from the CAVALLI phase 1b trial. Blood 2019, 133, 1964-1976. [CrossRef]

81. Al-Sawaf, O.; Lilienweiss, E.; Bahlo, J.; Robrecht, S.; Fink, A.M.; Patz, M.; Tandon, M.; Jiang, Y.; Schary, W.; Ritgen, M.; et al. High efficacy of venetoclax plus obinutuzumab in patients with complex karyotype and chronic lymphocytic leukemia. Blood 2020, 135, 866-870. [CrossRef]

82. Cramer, P.; Tausch, E.; von Tresckow, J.; Giza, A.; Robrecht, S.; Schneider, C.; Fürstenau, M.; Langerbeins, P.; Al-Sawaf, O.; Pelzer, B.W.; et al. Durable remissions following combined targeted therapy in patients with CLL harboring TP53 deletions and/or mutations. Blood 2021. [CrossRef]

83. Vazquez, R.; Breal, C.; Zalmai, L.; Friedrich, C.; Almire, C.; Contejean, A.; Barreau, S.; Grignano, E.; Willems, L.; Deau-Fischer, B.; et al. Venetoclax combination therapy induces deep AML remission with eradication of leukemic stem cells and remodeling of clonal haematopoiesis. Blood Cancer J. 2021, 11, 62. [CrossRef] [PubMed]

84. Lew, T.E.; Anderson, M.A.; Lin, V.S.; Handunnetti, S.M.; Came, N.A.; Blombery, P.; Westerman, D.A.; Wall, M.; Tam, C.S.; Roberts, A.W.; et al. Undetectable peripheral blood MRD should be the goal of venetoclax in CLL, but attainment plateaus after 24 months. Blood Adv. 2020, 4, 165-173. [CrossRef] 
85. Koehler, A.B.; Leung, N.; Call, T.G.; Rabe, K.G.; Achenbach, S.J.; Ding, W.; Kenderian, S.S.; Leis, J.F.; Wang, Y.; Muchtar, E.; et al. Incidence and risk of tumor lysis syndrome in patients with relapsed chronic lymphocytic leukemia (CLL) treated with venetoclax in routine clinical practice. Leuk. Lymphoma 2020, 61, 2383-2388. [CrossRef] [PubMed]

86. Gribben, J.G. Practical management of tumour lysis syndrome in venetoclax-treated patients with chronic lymphocytic leukaemia. Br. J. Haematol. 2020, 188, 844-851. [CrossRef] [PubMed]

87. Esparza, S.; Muluneh, B.; Galeotti, J.; Matson, M.; Richardson, D.R.; Montgomery, N.D.; Coombs, C.C.; Jamieson, K.; Foster, M.C.; Zeidner, J.F. Venetoclax-induced tumour lysis syndrome in acute myeloid leukaemia. Br. J. Haematol. 2020, 188, $173-177$. [CrossRef]

88. Thijssen, R.; Diepstraten, S.T.; Moujalled, D.; Chew, E.; Flensburg, C.; Shi, M.X.; Dengler, M.A.; Litalien, V.; MacRaild, S.; Chen, M.; et al. Intact TP-53 function is essential for sustaining durable responses to BH3-mimetic drugs in leukemias. Blood 2021, 137, 2721-2735. [CrossRef]

89. Tausch, E.; Schneider, C.; Robrecht, S.; Zhang, C.; Dolnik, A.; Bloehdorn, J.; Bahlo, J.; Al-Sawaf, O.; Ritgen, M.; Fink, A.M.; et al. Prognostic and predictive impact of genetic markers in patients with CLL treated with obinutuzumab and venetoclax. Blood 2020, 135, 2402-2412. [CrossRef] [PubMed]

90. Kim, K.; Maiti, A.; Loghavi, S.; Pourebrahim, R.; Kadia, T.M.; Rausch, C.R.; Furudate, K.; Daver, N.G.; Alvarado, Y.; Ohanian, M.; et al. Outcomes of TP53-mutant acute myeloid leukemia with decitabine and venetoclax. Cancer 2021. [CrossRef] [PubMed]

91. Lagadinou, E.D.; Sach, A.; Callahan, K.; Rossi, R.M.; Neering, S.J.; Minhajuddin, M.; Ashton, J.M.; Pei, S.; Grose, V.; O’Dwyer, K.M.; et al. BCL-2 inhibition targets oxidative phosphorylation and selectively eradicates quiescent human leukemia stem cells. Cell Stem Cell 2013, 12, 329-341. [CrossRef]

92. Liu, F.; Kalpage, H.A.; Wang, D.; Edwards, H.; Hüttemann, M.; Ma, J.; Su, Y.; Carter, J.; Li, X.; Polin, L.; et al. Cotargeting of mitochondrial complex I and Bcl-2 shows antileukemic activity against acute myeloid leukemia cells reliant on oxidative phosphorylation. Cancers 2020, 12, 2400. [CrossRef]

93. Roca-Portoles, A.; Rodriguez-Blanco, G.; Sumpton, D.; Cloix, C.; Mullin, M.; Mackay, G.M.; O’Neill, K.; Lemgruber, L.; Luo, X.; Tait, S.W.G. Venetoclax causes metabolic reprogramming independent of BCL-2 inhibition. Cell Death Dis. 2020, 11, 616. [CrossRef]

94. Lee, J.B.; Khan, D.H.; Hurren, R.; Xu, M.; Na, Y.; Kang, H.; Mirali, S.; Wang, X.; Gronda, M.; Jitkova, Y.; et al. Venetoclax enhances T cell-mediated antileukemic activity by increasing ROS production. Blood 2021, 138, 234-245. [CrossRef]

95. Blombery, P.; Thompson, E.R.; Nguyen, T.; Birkinshaw, R.W.; Gong, J.N.; Chen, X.; McBean, M.; Thijssen, R.; Conway, T.; Anderson, M.A.; et al. Multiple BCL2 mutations cooccurring with Gly101Val emerge in chronic lymphocytic leukemia progression on venetoclax. Blood 2020, 135, 773-777. [CrossRef] [PubMed]

96. Bhatt, S.; Pioso, M.S.; Olesinski, E.A.; Yilma, B.; Ryan, J.A.; Mashaka, T.; Leutz, B.; Adamia, S.; Zhu, H.; Kuang, Y.; et al. Reduced mitochondrial apoptotic priming drives resistance to BH3 mimetics in acute myeloid leukemia. Cancer Cell 2020, 38, 872-890.e6. [CrossRef]

97. Haselager, M.; Thijssen, R.; West, C.; Young, L.; Van Kampen, R.; Willmore, E.; Mackay, S.; Kater, A.; Eldering, E. Regulation of Bcl-XL by non-canonical NF-KB in the context of CD40-induced drug resistance in CLL. Cell Death Differ. 2021. [CrossRef] [PubMed]

98. Hernandez-Luna, M.A.; Rocha-Zavaleta, L.; Vega, M.I.; Huerta-Yepez, S. Hypoxia inducible factor- $1 \alpha$ induces chemoresistance phenotype in non-Hodgkin lymphoma cell line via up-regulation of Bcl-xL. Leuk. Lymphoma 2013, 54, 1048-1055. [CrossRef]

99. Chen, N.; Chen, X.; Huang, R.; Zeng, H.; Gong, J.; Meng, W.; Lu, Y.; Zhao, F.; Wang, L.; Zhou, Q. BCL-xL is a target gene regulated by hypoxia-inducible factor-1\{alpha\}. J. Biol. Chem. 2009, 284, 10004-10012. [CrossRef]

100. Haselager, M.V.; Kielbassa, K.; Ter Burg, J.; Bax, D.J.C.; Fernandes, S.M.; Borst, J.; Tam, C.; Forconi, F.; Chiodin, G.; Brown, J.R.; et al Changes in Bcl-2 members after ibrutinib or venetoclax uncover functional hierarchy in determining resistance to venetoclax in CLL. Blood 2020, 136, 2918-2926. [CrossRef] [PubMed]

101. Lucas, F.; Larkin, K.; Gregory, C.T.; Orwick, S.; Doong, T.J.; Lozanski, A.; Lozanski, G.; Misra, S.; Ngankeu, A.; Ozer, H.G.; et al. Novel BCL2 mutations in venetoclax-resistant, ibrutinib-resistant CLL patients with BTK/PLCG2 mutations. Blood 2020, 135, 2192-2195. [CrossRef]

102. Blombery, P.; Anderson, M.A.; Gong, J.N.; Thijssen, R.; Birkinshaw, R.W.; Thompson, E.R.; Teh, C.E.; Nguyen, T.; Xu, Z.; Flensburg, C.; et al. Acquisition of the recurrent Gly101Val mutation in BCL2 confers resistance to venetoclax in patients with progressive chronic lymphocytic leukemia. Cancer Discov. 2019, 9, 342-353. [CrossRef] [PubMed]

103. Birkinshaw, R.W.; Gong, J.N.; Luo, C.S.; Lio, D.; White, C.A.; Anderson, M.A.; Blombery, P.; Lessene, G.; Majewski, I.J.; Thijssen, R.; et al. Structures of BCL-2 in complex with venetoclax reveal the molecular basis of resistance mutations. Nat. Commun. 2019, 10, 2385. [CrossRef]

104. Zhang, X.; Qian, J.; Wang, H.; Wang, Y.; Zhang, Y.; Qian, P.; Lou, Y.; Jin, J.; Zhu, H. Not BCL2 mutation but dominant mutation conversation contributed to acquired venetoclax resistance in acute myeloid leukemia. Biomark. Res. 2021, 9, 30. [CrossRef] [PubMed]

105. Zhang, H.; Nakauchi, Y.; Köhnke, T.; Stafford, M.; Bottomly, D.; Thomas, R.; Wilmot, B.; McWeeney, S.K.; Majeti, R.; Tyner, J.W. Integrated analysis of patient samples identifies biomarkers for venetoclax efficacy and combination strategies in acute myeloid leukemia. Nat. Cancer 2020, 1, 826-839. [CrossRef] [PubMed] 
106. Nechiporuk, T.; Kurtz, S.E.; Nikolova, O.; Liu, T.; Jones, C.L.; D'Alessandro, A.; Culp-Hill, R.; d'Almeida, A.; Joshi, S.K.; Rosenberg, M.; et al. The TP53 apoptotic network is a primary mediator of resistance to BCL2 inhibition in AML cells. Cancer Discov. 2019, 9, 910-925. [CrossRef] [PubMed]

107. Chen, X.; Glytsou, C.; Zhou, H.; Narang, S.; Reyna, D.E.; Lopez, A.; Sakellaropoulos, T.; Gong, Y.; Kloetgen, A.; Yap, Y.S.; et al. Targeting mitochondrial structure sensitizes acute myeloid leukemia to venetoclax treatment. Cancer Discov. 2019, 9, 890-909. [CrossRef]

108. Shi, X.; Jiang, Y.; Kitano, A.; Hu, T.; Murdaugh, R.L.; Li, Y.; Hoegenauer, K.A.; Chen, R.; Takahashi, K.; Nakada, D. Nuclear NAD ${ }^{+}$ homeostasis governed by NMNAT1 prevents apoptosis of acute myeloid leukemia stem cells. Sci. Adv. 2021, 7. [CrossRef]

109. Stevens, B.M.; Jones, C.L.; Pollyea, D.A.; Culp-Hill, R.; D’Alessandro, A.; Winters, A.; Krug, A.; Abbott, D.; Goosman, M.; Pei, S.; et al. Fatty acid metabolism underlies venetoclax resistance in acute myeloid leukemia stem cells. Nat. Cancer 2020, 1, 1176-1187. [CrossRef]

110. Zhao, S.; Kanagal-Shamanna, R.; Navsaria, L.; Ok, C.Y.; Zhang, S.; Nomie, K.; Han, G.; Hao, D.; Hill, H.A.; Jiang, C.; et al. Efficacy of venetoclax in high risk relapsed mantle cell lymphoma (MCL)—Outcomes and mutation profile from venetoclax resistant MCL patients. Am. J. Hematol. 2020, 95, 623-629. [CrossRef] [PubMed]

111. Jin, S.; Cojocari, D.; Purkal, J.J.; Popovic, R.; Talaty, N.N.; Xiao, Y.; Solomon, L.R.; Boghaert, E.R.; Leverson, J.D.; Phillips, D.C. 5-Azacitidine induces NOXA to prime AML cells for venetoclax-mediated apoptosis. Clin. Cancer Res. Off. J. Am. Assoc. Cancer Res. 2020, 26, 3371-3383. [CrossRef] [PubMed]

112. Nguyen, L.X.T.; Troadec, E.; Kalvala, A.; Kumar, B.; Hoang, D.H.; Viola, D.; Zhang, B.; Nguyen, D.Q.; Aldoss, I.; Ghoda, L.; et al. The Bcl-2 inhibitor venetoclax inhibits Nrf2 antioxidant pathway activation induced by hypomethylating agents in AML. J. Cell. Physiol. 2019, 234, 14040-14049. [CrossRef] [PubMed]

113. Pollyea, D.A.; Stevens, B.M.; Jones, C.L.; Winters, A.; Pei, S.; Minhajuddin, M.; D’Alessandro, A.; Culp-Hill, R.; Riemondy, K.A.; Gillen, A.E.; et al. Venetoclax with azacitidine disrupts energy metabolism and targets leukemia stem cells in patients with acute myeloid leukemia. Nat. Med. 2018, 24, 1859-1866. [CrossRef]

114. Moujalled, D.M.; Pomilio, G.; Ghiurau, C.; Ivey, A.; Salmon, J.; Rijal, S.; Macraild, S.; Zhang, L.; Teh, T.C.; Tiong, I.S.; et al. Combining BH3-mimetics to target both BCL-2 and MCL1 has potent activity in pre-clinical models of acute myeloid leukemia. Leukemia 2019, 33, 905-917. [CrossRef]

115. Jain, N.; Gandhi, V.; Wierda, W. Ibrutinib and venetoclax for first-line treatment of CLL. reply. N. Engl. J. Med. 2019, 381, 789. [CrossRef]

116. Hillmen, P.; Rawstron, A.C.; Brock, K.; Muñoz-Vicente, S.; Yates, F.J.; Bishop, R.; Boucher, R.; MacDonald, D.; Fegan, C.; McCaig, A.; et al. Ibrutinib plus venetoclax in relapsed/refractory chronic lymphocytic leukemia: The CLARITY study. J. Clin. Oncol. Off. J. Am. Soc. Clin. Oncol. 2019, 37, 2722-2729. [CrossRef] [PubMed]

117. Lu, P.; Wang, S.; Franzen, C.A.; Venkataraman, G.; McClure, R.; Li, L.; Wu, W.; Niu, N.; Sukhanova, M.; Pei, J.; et al. Ibrutinib and venetoclax target distinct subpopulations of CLL cells: Implication for residual disease eradication. Blood Cancer J. 2021, 11, 39. [CrossRef] [PubMed]

118. Luo, Q.; Pan, W.; Zhou, S.; Wang, G.; Yi, H.; Zhang, L.; Yan, X.; Yuan, L.; Liu, Z.; Wang, J.; et al. A novel BCL-2 inhibitor APG-2575 exerts synthetic lethality with BTK or MDM2-p53 inhibitor in diffuse large B-cell lymphoma. Oncol. Res. 2020, 28, 331-344. [CrossRef]

119. Kozopas, K.M.; Yang, T.; Buchan, H.L.; Zhou, P.; Craig, R.W. MCL1, a gene expressed in programmed myeloid cell differentiation, has sequence similarity to BCL2. Proc. Natl. Acad. Sci. USA 1993, 90, 3516-3520. [CrossRef] [PubMed]

120. Leuenroth, S.J.; Grutkoski, P.S.; Ayala, A.; Simms, H.H. The loss of Mcl-1 expression in human polymorphonuclear leukocytes promotes apoptosis. J. Leukoc. Biol. 2000, 68, 158-166.

121. Yang, T.; Kozopas, K.M.; Craig, R.W. The intracellular distribution and pattern of expression of Mcl-1 overlap with, but are not identical to, those of Bcl-2. J. Cell Biol. 1995, 128, 1173-1184. [CrossRef]

122. Day, C.L.; Chen, L.; Richardson, S.J.; Harrison, P.J.; Huang, D.C.; Hinds, M.G. Solution structure of prosurvival Mcl-1 and characterization of its binding by proapoptotic BH3-only ligands. J. Biol. Chem. 2005, 280, 4738-4744. [CrossRef]

123. Senichkin, V.V.; Streletskaia, A.Y.; Gorbunova, A.S.; Zhivotovsky, B.; Kopeina, G.S. Saga of Mcl-1: Regulation from transcription to degradation. Cell Death Differ. 2020, 27, 405-419. [CrossRef]

124. Thomas, L.W.; Lam, C.; Edwards, S.W. Mcl-1; the molecular regulation of protein function. FEBS Lett. 2010, 584, 2981-2989. [CrossRef]

125. Gomez-Bougie, P.; Menoret, E.; Juin, P.; Dousset, C.; Pellat-Deceunynck, C.; Amiot, M. Noxa controls Mule-dependent Mcl-1 ubiquitination through the regulation of the Mcl-1/USP9X interaction. Biochem. Biophys. Res. Commun. 2011, 413, 460-464. [CrossRef] [PubMed]

126. Wu, X.; Luo, Q.; Liu, Z. Ubiquitination and deubiquitination of MCL1 in cancer: Deciphering chemoresistance mechanisms and providing potential therapeutic options. Cell Death Dis. 2020, 11, 556. [CrossRef]

127. Zhong, Q.; Gao, W.; Du, F.; Wang, X. Mule/ARF-BP1, a BH3-only E3 ubiquitin ligase, catalyzes the polyubiquitination of Mcl-1 and regulates apoptosis. Cell 2005, 121, 1085-1095. [CrossRef] [PubMed]

128. Xiang, W.; Yang, C.Y.; Bai, L. MCL-1 inhibition in cancer treatment. OncoTargets Ther. 2018, 11, 7301-7314. [CrossRef]

129. Rinkenberger, J.L.; Horning, S.; Klocke, B.; Roth, K.; Korsmeyer, S.J. Mcl-1 deficiency results in peri-implantation embryonic lethality. Genes Dev. 2000, 14, 23-27. 
130. Chin, H.S.; Fu, N.Y. Physiological functions of Mcl-1: Insights from genetic mouse models. Front. Cell Dev. Biol. 2021, 9, 704547. [CrossRef] [PubMed]

131. Koss, B.; Morrison, J.; Perciavalle, R.M.; Singh, H.; Rehg, J.E.; Williams, R.T.; Opferman, J.T. Requirement for antiapoptotic MCL-1 in the survival of BCR-ABL B-lineage acute lymphoblastic leukemia. Blood 2013, 122, 1587-1598. [CrossRef] [PubMed]

132. Opferman, J.T.; Letai, A.; Beard, C.; Sorcinelli, M.D.; Ong, C.C.; Korsmeyer, S.J. Development and maintenance of B and T lymphocytes requires antiapoptotic MCL-1. Nature 2003, 426, 671-676. [CrossRef]

133. Perciavalle, R.M.; Stewart, D.P.; Koss, B.; Lynch, J.; Milasta, S.; Bathina, M.; Temirov, J.; Cleland, M.M.; Pelletier, S.; Schuetz, J.D.; et al. Anti-apoptotic MCL-1 localizes to the mitochondrial matrix and couples mitochondrial fusion to respiration. Nat. Cell Biol. 2012, 14, 575-583. [CrossRef]

134. Escudero, S.; Zaganjor, E.; Lee, S.; Mill, C.P.; Morgan, A.M.; Crawford, E.B.; Chen, J.; Wales, T.E.; Mourtada, R.; Luccarelli, J.; et al. Dynamic regulation of long-chain fatty acid oxidation by a noncanonical interaction between the MCL-1 BH3 helix and VLCAD. Mol. Cell 2018, 69, 729-743.e7. [CrossRef]

135. Wei, A.H.; Roberts, A.W.; Spencer, A.; Rosenberg, A.S.; Siegel, D.; Walter, R.B.; Caenepeel, S.; Hughes, P.; McIver, Z.; Mezzi, K.; et al. Targeting MCL-1 in hematologic malignancies: Rationale and progress. Blood Rev. 2020, 44, 100672. [CrossRef] [PubMed]

136. Beroukhim, R.; Mermel, C.H.; Porter, D.; Wei, G.; Raychaudhuri, S.; Donovan, J.; Barretina, J.; Boehm, J.S.; Dobson, J.; Urashima, M.; et al. The landscape of somatic copy-number alteration across human cancers. Nature 2010, 463, 899-905. [CrossRef]

137. Zhou, P.; Levy, N.B.; Xie, H.; Qian, L.; Lee, C.Y.; Gascoyne, R.D.; Craig, R.W. MCL1 transgenic mice exhibit a high incidence of B-cell lymphoma manifested as a spectrum of histologic subtypes. Blood 2001, 97, 3902-3909. [CrossRef]

138. Grabow, S.; Delbridge, A.R.; Aubrey, B.J.; Vandenberg, C.J.; Strasser, A. Loss of a single Mcl-1 allele inhibits MYC-driven lymphomagenesis by sensitizing pro-B cells to apoptosis. Cell Rep. 2016, 14, 2337-2347. [CrossRef] [PubMed]

139. Wenzel, S.S.; Grau, M.; Mavis, C.; Hailfinger, S.; Wolf, A.; Madle, H.; Deeb, G.; Dörken, B.; Thome, M.; Lenz, P.; et al. MCL1 is deregulated in subgroups of diffuse large B-cell lymphoma. Leukemia 2013, 27, 1381-1390. [CrossRef]

140. Awan, F.T.; Kay, N.E.; Davis, M.E.; Wu, W.; Geyer, S.M.; Leung, N.; Jelinek, D.F.; Tschumper, R.C.; Secreto, C.R.; Lin, T.S.; et al. Mcl-1 expression predicts progression-free survival in chronic lymphocytic leukemia patients treated with pentostatin, cyclophosphamide, and rituximab. Blood 2009, 113, 535-537. [CrossRef]

141. Pepper, C.; Lin, T.T.; Pratt, G.; Hewamana, S.; Brennan, P.; Hiller, L.; Hills, R.; Ward, R.; Starczynski, J.; Austen, B.; et al. Mcl-1 expression has in vitro and in vivo significance in chronic lymphocytic leukemia and is associated with other poor prognostic markers. Blood 2008, 112, 3807-3817. [CrossRef]

142. Kaufmann, S.H.; Karp, J.E.; Svingen, P.A.; Krajewski, S.; Burke, P.J.; Gore, S.D.; Reed, J.C. Elevated expression of the apoptotic regulator Mcl-1 at the time of leukemic relapse. Blood 1998, 91, 991-1000. [CrossRef]

143. Slomp, A.; Moesbergen, L.M.; Gong, J.N.; Cuenca, M.; von dem Borne, P.A.; Sonneveld, P.; Huang, D.C.S.; Minnema, M.C.; Peperzak, V. Multiple myeloma with 1q21 amplification is highly sensitive to MCL-1 targeting. Blood Adv. 2019, 3, 4202-4214. [CrossRef]

144. Kelly, G.L.; Grabow, S.; Glaser, S.P.; Fitzsimmons, L.; Aubrey, B.J.; Okamoto, T.; Valente, L.J.; Robati, M.; Tai, L.; Fairlie, W.D.; et al. Targeting of MCL-1 kills MYC-driven mouse and human lymphomas even when they bear mutations in p53. Genes Dev. 2014, 28, 58-70. [CrossRef] [PubMed]

145. Tron, A.E.; Belmonte, M.A.; Adam, A.; Aquila, B.M.; Boise, L.H.; Chiarparin, E.; Cidado, J.; Embrey, K.J.; Gangl, E.; Gibbons, F.D.; et al. Discovery of Mcl-1-specific inhibitor AZD5991 and preclinical activity in multiple myeloma and acute myeloid leukemia. Nat. Commun. 2018, 9, 5341. [CrossRef] [PubMed]

146. Yi, X.; Sarkar, A.; Kismali, G.; Aslan, B.; Ayres, M.; Iles, L.R.; Keating, M.J.; Wierda, W.G.; Long, J.P.; Bertilaccio, M.T.S.; et al. AMG-176, an Mcl-1 antagonist, shows preclinical efficacy in chronic lymphocytic leukemia. Clin. Cancer Res. Off. J. Am. Assoc. Cancer Res. 2020, 26, 3856-3867. [CrossRef]

147. Rasmussen, M.L.; Taneja, N.; Neininger, A.C.; Wang, L.; Robertson, G.L.; Riffle, S.N.; Shi, L.; Knollmann, B.C.; Burnette, D.T.; Gama, V. MCL-1 inhibition by selective BH3 mimetics disrupts mitochondrial dynamics causing loss of viability and functionality of human cardiomyocytes. iScience 2020, 23, 101015. [CrossRef]

148. Phillips, D.C.; Jin, S.; Gregory, G.P.; Zhang, Q.; Xue, J.; Zhao, X.; Chen, J.; Tong, Y.; Zhang, H.; Smith, M.; et al. A novel CDK9 inhibitor increases the efficacy of venetoclax (ABT-199) in multiple models of hematologic malignancies. Leukemia 2020, 34, 1646-1657. [CrossRef] [PubMed]

149. Cidado, J.; Boiko, S.; Proia, T.; Ferguson, D.; Criscione, S.W.; San Martin, M.; Pop-Damkov, P.; Su, N.; Roamio Franklin, V.N.; Sekhar Reddy Chilamakuri, C.; et al. AZD4573 is a highly selective CDK9 inhibitor that suppresses MCL-1 and induces apoptosis in hematologic cancer cells. Clin. Cancer Res. Off. J. Am. Assoc. Cancer Res. 2020, 26, 922-934. [CrossRef] [PubMed]

150. Zhang, Y.; Zhou, L.; Bandyopadhyay, D.; Sharma, K.; Allen, A.J.; Kmieciak, M.; Grant, S. The covalent CDK7 inhibitor THZ1 potently induces apoptosis in multiple myeloma cells in vitro and in vivo. Clin. Cancer Res. Off. J. Am. Assoc. Cancer Res. 2019, 25, 6195-6205. [CrossRef]

151. Boiko, S.; Proia, T.; San Martin, M.; Gregory, G.P.; Wu, M.M.; Aryal, N.; Hattersley, M.; Shao, W.; Saeh, J.C.; Fawell, S.E.; et al. Targeting Bfl-1 via acute CDK9 inhibition overcomes intrinsic BH3-mimetic resistance in lymphomas. Blood 2021, 137, $2947-2957$. [CrossRef] [PubMed]

152. Boise, L.H.; Gonzalez-Garcia, M.; Postema, C.E.; Ding, L.; Lindsten, T.; Turka, L.A.; Mao, X.; Nunez, G.; Thompson, C.B. bcl-x, a bcl-2-related gene that functions as a dominant regulator of apoptotic cell death. Cell 1993, 74, 597-608. [CrossRef] 
153. Muchmore, S.W.; Sattler, M.; Liang, H.; Meadows, R.P.; Harlan, J.E.; Yoon, H.S.; Nettesheim, D.; Chang, B.S.; Thompson, C.B.; Wong, S.L.; et al. X-ray and NMR structure of human Bcl-xL, an inhibitor of programmed cell death. Nature 1996, 381, 335-341. [CrossRef] [PubMed]

154. Motoyama, N.; Wang, F.; Roth, K.A.; Sawa, H.; Nakayama, K.; Nakayama, K.; Negishi, I.; Senju, S.; Zhang, Q.; Fujii, S.; et al. Massive cell death of immature hematopoietic cells and neurons in Bcl-x-deficient mice. Science 1995, 267, 1506-1510. [CrossRef]

155. Kaufmann, T.; Schlipf, S.; Sanz, J.; Neubert, K.; Stein, R.; Borner, C. Characterization of the signal that directs Bcl-x(L), but not Bcl-2, to the mitochondrial outer membrane. J. Cell Biol. 2003, 160, 53-64. [CrossRef]

156. Lee, E.F.; Fairlie, W.D. The structural biology of Bcl-xL. Int. J. Mol. Sci. 2019, 20, 2234. [CrossRef]

157. Liu, X.; Dai, S.; Zhu, Y.; Marrack, P.; Kappler, J.W. The structure of a Bcl-xL/Bim fragment complex: Implications for Bim function. Immunity 2003, 19, 341-352. [CrossRef]

158. Edlich, F.; Banerjee, S.; Suzuki, M.; Cleland, M.M.; Arnoult, D.; Wang, C.; Neutzner, A.; Tjandra, N.; Youle, R.J. Bcl-x(L) retrotranslocates Bax from the mitochondria into the cytosol. Cell 2011, 145, 104-116. [CrossRef]

159. Monaco, G.; Decrock, E.; Akl, H.; Ponsaerts, R.; Vervliet, T.; Luyten, T.; De Maeyer, M.; Missiaen, L.; Distelhorst, C.W.; De Smedt, $\mathrm{H}$; et al. Selective regulation of IP3-receptor-mediated Ca2+ signaling and apoptosis by the BH4 domain of Bcl-2 versus Bcl-X1. Cell Death Differ. 2012, 19, 295-309. [CrossRef] [PubMed]

160. Vander Heiden, M.G.; Li, X.X.; Gottleib, E.; Hill, R.B.; Thompson, C.B.; Colombini, M. Bcl-xL promotes the open configuration of the voltage-dependent anion channel and metabolite passage through the outer mitochondrial membrane. J. Biol. Chem. 2001, 276, 19414-19419. [CrossRef] [PubMed]

161. Williams, A.; Hayashi, T.; Wolozny, D.; Yin, B.; Su, T.C.; Betenbaugh, M.J.; Su, T.P. The non-apoptotic action of Bcl-xL: Regulating $\mathrm{Ca}^{2+}$ signaling and bioenergetics at the ER-mitochondrion interface. J. Bioenerg. Biomembr. 2016, 48, 211-225. [CrossRef]

162. Maiuri, M.C.; Le Toumelin, G.; Criollo, A.; Rain, J.C.; Gautier, F.; Juin, P.; Tasdemir, E.; Pierron, G.; Troulinaki, K.; Tavernarakis, N.; et al. Functional and physical interaction between Bcl-X(L) and a BH3-like domain in Beclin-1. EMBO J. 2007, 26, 2527-2539. [CrossRef]

163. Afreen, S.; Bohler, S.; Muller, A.; Demmerath, E.M.; Weiss, J.M.; Jutzi, J.S.; Schachtrup, K.; Kunze, M.; Erlacher, M. BCL-XL expression is essential for human erythropoiesis and engraftment of hematopoietic stem cells. Cell Death Dis. 2020, 11, 8. [CrossRef] [PubMed]

164. Chao, D.T.; Linette, G.P.; Boise, L.H.; White, L.S.; Thompson, C.B.; Korsmeyer, S.J. Bcl-XL and Bcl-2 repress a common pathway of cell death. J. Exp. Med. 1995, 182, 821-828. [CrossRef] [PubMed]

165. Kelly, P.N.; Grabow, S.; Delbridge, A.R.; Strasser, A.; Adams, J.M. Endogenous Bcl-xL is essential for Myc-driven lymphomagenesis in mice. Blood 2011, 118, 6380-6386. [CrossRef]

166. Konopleva, M.; Zhao, S.; Hu, W.; Jiang, S.; Snell, V.; Weidner, D.; Jackson, C.E.; Zhang, X.; Champlin, R.; Estey, E.; et al. The anti-apoptotic genes Bcl- $\mathrm{X}_{\mathrm{L}}$ and $\mathrm{Bcl}-2$ are over-expressed and contribute to chemoresistance of non-proliferating leukaemic $\mathrm{CD}^{+} 4^{+}$ cells. Br. J. Haematol. 2002, 118, 521-534. [CrossRef]

167. Shoemaker, A.R.; Oleksijew, A.; Bauch, J.; Belli, B.A.; Borre, T.; Bruncko, M.; Deckwirth, T.; Frost, D.J.; Jarvis, K.; Joseph, M.K.; et al. A small-molecule inhibitor of Bcl-XL potentiates the activity of cytotoxic drugs in vitro and in vivo. Cancer Res. 2006, 66, 8731-8739. [CrossRef] [PubMed]

168. Kerkhofs, M.; Vervloessem, T.; Stopa, K.B.; Smith, V.M.; Vogler, M.; Bultynck, G. DLBCL Cells with acquired resistance to Venetoclax are not sensitized to BIRD-2 but can be resensitized to venetoclax through Bcl-XL inhibition. Biomolecules 2020, $10,1081$. [CrossRef]

169. Pullarkat, V.A.; Lacayo, N.J.; Jabbour, E.; Rubnitz, J.E.; Bajel, A.; Laetsch, T.W.; Leonard, J.; Colace, S.I.; Khaw, S.L.; Fleming, S.A.; et al. Venetoclax and navitoclax in combination with chemotherapy in patients with relapsed or refractory acute lymphoblastic leukemia and lymphoblastic lymphoma. Cancer Discov. 2021, 11, 1440-1453. [CrossRef]

170. Arulananda, S.; O’Brien, M.; Evangelista, M.; Jenkins, L.J.; Poh, A.R.; Walkiewicz, M.; Leong, T.; Mariadason, J.M.; Cebon, J.; Balachander, S.B.; et al. A novel BH3-mimetic, AZD0466, targeting BCL-XL and BCL-2 is effective in pre-clinical models of malignant pleural mesothelioma. Cell Death Discov. 2021, 7, 122. [CrossRef] [PubMed]

171. Balachander, S.B.; Criscione, S.W.; Byth, K.F.; Cidado, J.; Adam, A.; Lewis, P.; Macintyre, T.; Wen, S.; Lawson, D.; Burke, K.; et al. AZD4320, a dual inhibitor of Bcl-2 and $\mathrm{Bcl}-\mathrm{x}_{\mathrm{L}}$, induces tumor regression in hematologic cancer models without dose-limiting thrombocytopenia. Clin. Cancer Res. Off. J. Am. Assoc. Cancer Res. 2020, 26, 6535-6549. [CrossRef]

172. Gibson, L.; Holmgreen, S.P.; Huang, D.C.; Bernard, O.; Copeland, N.G.; Jenkins, N.A.; Sutherland, G.R.; Baker, E.; Adams, J.M.; Cory, S. bcl-w, a novel member of the bcl-2 family, promotes cell survival. Oncogene 1996, 13, 665-675. [PubMed]

173. O’Reilly, L.A.; Print, C.; Hausmann, G.; Moriishi, K.; Cory, S.; Huang, D.C.; Strasser, A. Tissue expression and subcellular localization of the pro-survival molecule Bcl-w. Cell Death Differ. 2001, 8, 486-494. [CrossRef]

174. Print, C.G.; Loveland, K.L.; Gibson, L.; Meehan, T.; Stylianou, A.; Wreford, N.; de Kretser, D.; Metcalf, D.; Kontgen, F.; Adams, J.M.; et al. Apoptosis regulator bcl-w is essential for spermatogenesis but appears otherwise redundant. Proc. Natl. Acad. Sci. USA 1998, 95, 12424-12431. [CrossRef]

175. Yan, W.; Samson, M.; Jegou, B.; Toppari, J. Bcl-w forms complexes with Bax and Bak, and elevated ratios of Bax/Bcl-w and Bak/Bcl-w correspond to spermatogonial and spermatocyte apoptosis in the testis. Mol. Endocrinol. 2000, 14, 682-699. [CrossRef] [PubMed] 
176. Adams, C.M.; Kim, A.S.; Mitra, R.; Choi, J.K.; Gong, J.Z.; Eischen, C.M. BCL-W has a fundamental role in B cell survival and lymphomagenesis. J. Clin. Investig. 2017, 127, 635-650. [CrossRef] [PubMed]

177. Beverly, L.J.; Varmus, H.E. MYC-induced myeloid leukemogenesis is accelerated by all six members of the antiapoptotic BCL family. Oncogene 2009, 28, 1274-1279. [CrossRef] [PubMed]

178. Diepstraten, S.T.; Chang, C.; Tai, L.; Gong, J.N.; Lan, P.; Dowell, A.C.; Taylor, G.S.; Strasser, A.; Kelly, G.L. BCL-W is dispensable for the sustained survival of select Burkitt lymphoma and diffuse large B-cell lymphoma cell lines. Blood Adv. 2020, 4, 356-366. [CrossRef]

179. D'Sa-Eipper, C.; Chinnadurai, G. Functional dissection of Bfl-1, a Bcl-2 homolog: Anti-apoptosis, oncogene-cooperation and cell proliferation activities. Oncogene 1998, 16, 3105-3114. [CrossRef] [PubMed]

180. Lin, E.Y.; Orlofsky, A.; Wang, H.G.; Reed, J.C.; Prystowsky, M.B. A1, a Bcl-2 family member, prolongs cell survival and permits myeloid differentiation. Blood 1996, 87, 983-992. [CrossRef]

181. Ottina, E.; Grespi, F.; Tischner, D.; Soratroi, C.; Geley, S.; Ploner, A.; Reichardt, H.M.; Villunger, A.; Herold, M.J. Targeting antiapoptotic A1/Bfl-1 by in vivo RNAi reveals multiple roles in leukocyte development in mice. Blood 2012, 119, 6032-6042. [CrossRef] [PubMed]

182. Schenk, R.L.; Tuzlak, S.; Carrington, E.M.; Zhan, Y.; Heinzel, S.; Teh, C.E.; Gray, D.H.; Tai, L.; Lew, A.M.; Villunger, A.; et al. Characterisation of mice lacking all functional isoforms of the pro-survival BCL-2 family member A1 reveals minor defects in the haematopoietic compartment. Cell Death Differ. 2017, 24, 534-545. [CrossRef]

183. Carrington, E.M.; Zhan, Y.; Brady, J.L.; Zhang, J.G.; Sutherland, R.M.; Anstee, N.S.; Schenk, R.L.; Vikstrom, I.B.; Delconte, R.B.; Segal, D.; et al. Anti-apoptotic proteins BCL-2, MCL-1 and A1 summate collectively to maintain survival of immune cell populations both in vitro and in vivo. Cell Death Differ. 2017, 24, 878-888. [CrossRef] [PubMed]

184. Karsan, A.; Yee, E.; Harlan, J.M. Endothelial cell death induced by tumor necrosis factor-alpha is inhibited by the Bcl-2 family member, A1. J. Biol. Chem. 1996, 271, 27201-27204. [CrossRef] [PubMed]

185. Mensink, M.; Anstee, N.S.; Robati, M.; Schenk, R.L.; Herold, M.J.; Cory, S.; Vandenberg, C.J. Anti-apoptotic A1 is not essential for lymphoma development in Emicro-Myc mice but helps sustain transplanted Emicro-Myc tumour cells. Cell Death Differ. 2018, 25, 797-808. [CrossRef]

186. Sochalska, M.; Schuler, F.; Weiss, J.G.; Prchal-Murphy, M.; Sexl, V.; Villunger, A. MYC selects against reduced BCL2A1/A1 protein expression during B cell lymphomagenesis. Oncogene 2017, 36, 2066-2073. [CrossRef]

187. Yecies, D.; Carlson, N.E.; Deng, J.; Letai, A. Acquired resistance to ABT-737 in lymphoma cells that up-regulate MCL-1 and BFL-1. Blood 2010, 115, 3304-3313. [CrossRef]

188. D'Souza, B.; Rowe, M.; Walls, D. The bfl-1 gene is transcriptionally upregulated by the Epstein-Barr virus LMP1, and its expression promotes the survival of a Burkitt's lymphoma cell line. J. Virol. 2000, 74, 6652-6658. [CrossRef]

189. Brien, G.; Trescol-Biemont, M.C.; Bonnefoy-Berard, N. Downregulation of Bfl-1 protein expression sensitizes malignant B cells to apoptosis. Oncogene 2007, 26, 5828-5832. [CrossRef]

190. Esteve-Arenys, A.; Roue, G. BFL-1 expression determines the efficacy of venetoclax in MYC+/BCL2+ double hit lymphoma. Oncoscience 2018, 5, 59-61. [CrossRef]

191. Li, X.; Dou, J.; You, Q.; Jiang, Z. Inhibitors of BCL2A1/Bfl-1 protein: Potential stock in cancer therapy. Eur. J. Med. Chem. 2021, 220, 113539. [CrossRef] [PubMed]

192. Ni Chonghaile, T.; Sarosiek, K.A.; Vo, T.T.; Ryan, J.A.; Tammareddi, A.; Moore Vdel, G.; Deng, J.; Anderson, K.C.; Richardson, P.; Tai, Y.T.; et al. Pretreatment mitochondrial priming correlates with clinical response to cytotoxic chemotherapy. Science 2011, 334, 1129-1133. [CrossRef]

193. Montero, J.; Sarosiek, K.A.; DeAngelo, J.D.; Maertens, O.; Ryan, J.; Ercan, D.; Piao, H.; Horowitz, N.S.; Berkowitz, R.S.; Matulonis, U.; et al. Drug-induced death signaling strategy rapidly predicts cancer response to chemotherapy. Cell 2015, 160, 977-989. [CrossRef] [PubMed]

194. Deng, J.; Carlson, N.; Takeyama, K.; Dal Cin, P.; Shipp, M.; Letai, A. BH3 profiling identifies three distinct classes of apoptotic blocks to predict response to ABT-737 and conventional chemotherapeutic agents. Cancer Cell 2007, 12, 171-185. [CrossRef] [PubMed] 